\title{
Cyclicality of Wages and Union Power
}

\author{
Morin, Annaïg
}

Document Version

Final published version

Publication date:

2016

\section{License \\ CC BY-NC-ND}

Citation for published version (APA):

Morin, A. (2016). Cyclicality of Wages and Union Power. Copenhagen Business School, CBS.

Link to publication in CBS Research Portal

\section{General rights}

Copyright and moral rights for the publications made accessible in the public portal are retained by the authors and/or other copyright owners and it is a condition of accessing publications that users recognise and abide by the legal requirements associated with these rights.

\section{Take down policy}

If you believe that this document breaches copyright please contact us (research.lib@cbs.dk) providing details, and we will remove access to the work immediately and investigate your claim. 


\title{
Cyclicality of Wages and Union Power
}

\author{
Annaïg Morin* \\ Copenhagen Business School
}

March 2016

\begin{abstract}
This paper examines how trade unions shape the volatility of wages over the business cycle. I present a dynamic stochastic model of the labor market that integrates two main features: search frictions and trade unions. Because of search frictions, each job match yields an economic surplus that is shared by the bargained wage. Therefore, I can decompose the volatility of wages into two components: the volatility of the match surplus and the volatility of the worker share of the surplus. Starting from the unions' objective function, I demonstrate that, under collective wage bargaining, the worker share is endogenous and countercyclical. Consequently, when the economy is hit by a shock, the dynamics of the worker share partially counteract the dynamics of the match surplus and this mechanism delivers endogenous wage rigidity. The model thus sheds new insights into two business cycle features: the union wage premium fluctuates countercyclically, and employment is more cyclically sensitive but less persistent when wages are collectively bargained.
\end{abstract}

Keywords: Search and matching; Trade unions; Cycles JEL classification: J64; J51; E32

*Department of Economics, Copenhagen Business School, Denmark. Email: amo.eco@cbs.dk. Web: www.annaig.com. I am grateful to Tito Boeri, Antonella Trigari and Alain Sand for their valuable advice and support. Moreover, I thank Alberto Alesina, Christian Bauer, Mickael Burda, Vincenzo Cuciniello, Szabolcs Deák, Matthias Doepke, Maja Ferjancic, Claudio Lucifora, Nicola Pavoni, Salvador Ortigueira, Martin Schneider, Francesco Zanetti and seminar participants at Bocconi university, GATE-Lyon II University, the 2010 European Workshop in Macroeconomics, WIEM 2010, AFSE 2010, ISNE 2010, ASSET 2010, RES 2011, IAB Workshop 2011 and EEA 2011 for their very useful comments. Additionally, I thank the Department of Economics at Bocconi University and Department of Economics at University of Lyon II for their support while I was working on earlier versions of this paper. 


\section{Introduction}

The role of trade unions is to protect the rights and interests of their members through representation within firms. In so doing, trade unions negotiate with employers on behalf of workers for better wages and working conditions. Therefore, through their direct participation in the wage determination process, trade unions affect the wage level and shape its volatility. This paper integrates trade unions into a dynamic search and matching framework that specifies two important sources of wage volatility: the volatility of the total match surplus and the volatility of the worker share, which is formally defined as the share of the total surplus obtained by workers. I study how these two sources of wage volatility interact over the business cycle to elucidate the cyclical properties of collectively-bargained wages, labor market tightness, employment, and union wage premia.

Specifically, this paper builds on Mortensen and Pissarides' (1994) search and matching model by introducing trade unions to the model. Although this theoretical framework accommodates different rent-sharing rules, i.e., different wage-setting processes, most of the search and matching literature proposes an individual Nash bargaining solution. Alternatives have recently been investigated, often to improve the ability of the model to explain the stylized facts of the business cycle. ${ }^{1}$ Within this growing strand of literature, few papers focus on collective wage bargaining. Yet, collective bargaining coverage remains high, even though union density has declined overall, ${ }^{2}$ and because of their direct participation in wage negotiations, unions necessarily affect not only the level but also the volatility of wages. Pissarides (1986) first integrated trade unions, in the form of a single monopoly union, into a search and matching framework, and Delacroix (2006) and Garibaldi and Violante (2005) subsequently extended his work. These authors model wage determination in the presence of trade unions and describe the negative impact of the union wage premium on employment. However, they propose steady state analyses that do not provide insight into the specific volatility of collectively bargained wages.

I develop and simulate a model of collective wage bargaining and compare the labor market dynamics with those characterizing individual wage bargaining. In so doing, I am able to identify the role of trade unions in shaping the volatility of labor market variables. The unions' utility function increases in both wages and employment, and the labor demand embodies the trade-off faced by unions. I decompose the mechanism through which unions affects wage dynamics in three steps. First, I demonstrate that the unions' preferences regarding employment and wages, defined as the marginal rate of substitution between them, directly

\footnotetext{
${ }^{1}$ Shimer (2005) notes that at conventional parameters values, individually Nash bargained wages are excessively volatile, depressing vacancy creation. Consequently, employment is far less volatile in the model than in the data. Wage rigidity has been explored as a way to improve the performance of the model.

${ }^{2}$ For a recent study on wage bargaining institutions in most European countries, the U.S., and Japan, see Du Caju, Gautier, Momferatou, and Ward-Warmedinger (2008). Among other results, they provide evidence on collective bargaining coverage and establish that this rate exceeds $80 \%$ in most western European countries.
} 
translate into the worker share of the surplus, i.e., the fraction of the total match surplus obtained by the workers. Indeed, when unions favor employment, they lower the worker share to boost the firms' surplus and vacancy postings. Conversely, when unions favor wages, they demand a high worker share.

Second, I show that the unions' preferences and therefore the labor share fluctuate endogenously. When the economy is hit by an adverse productivity shock, given the higher reactivity of wages compared with employment, the unions' first concern is to avoid a large decrease in the wage rate. Therefore, on impact, unions prioritize wages over employment and exert upward pressure on the worker share. In subsequent periods, as the adverse shock propagates into the economy and as unemployment increases, unions become more employmentoriented, diminishing the worker share. This second finding is consistent with empirical evidence suggesting that the unions' power to raise wages is reduced when unemployment is high. ${ }^{3}$ The unions' behavior is therefore entirely explained by changes in the relative weights given to wages and employment over the business cycle, and because the cyclical properties of the unions' preferences directly determine the cyclical properties of the worker share, the worker share is countercyclical and features little persistence.

Third, the wage equation indicates that wages increase with both the total match surplus and the labor share. Under collective wage bargaining, the countercyclical fluctuations in the labor share dampen the procyclical fluctuations of wages, and this mechanism endogenously generates wage rigidity. Furthermore, the low persistence in the worker share dynamics, which is explained by the change in the union's preferences over the business cycle, translates into high persistence in the wage dynamics. I also investigate the cyclical properties of the union wage premium. Because the fluctuations in the labor share represent an additional source of wage volatility for collectively bargained wages only, I find that the union wage premium widens after an adverse shock. The model therefore provides a theoretical rationale for the countercyclicality of the union wage premium that has been documented by several empirical studies. For example, in their book entitled What do unions do?, Freeman and Medoff (1984) show that unions behave more aggressively in poor economic times. Their underlying argument differs slightly from the present argument, as they explain that the countercyclicality of the union wage premium observed during the depression of the 1920s and 1930s is mainly driven by 'the greater capacity of unionized workers to fight employers' effort to reduce

\footnotetext{
${ }^{3}$ Using time series data for the Swedish construction sector, Aronsson, Löfgren, and Wikström (1993) test two models of wage determination: one in which the bargaining power of the union is constant over time and another one in which the bargaining power develops with unemployment and labor market characteristics. They find evidence that unemployment tends to decrease the bargaining power of the union. Campbell (1997) empirically confirms this result. Using U.S. data, he finds that union wages are more sensitive than nonunion wages to the unemployment rate. See also Calmfors, Booth, Burda, Checchi, Naylor, and Visser (2001), Part I, chapter 2.4, for a literature review on the negative relation between unemployment and union membership, which is based on the argument that "in times of high and rising unemployment, unions are less able to press demands and obtain advantages for members."
} 
wages" when market conditions are unfavorable. Based on an empirical study of the union wage premium in the U.S. over the 1973-2002 period, Blanchflower and Bryson (2004) also find that the union wage premium widens during recessions.

Therefore, in this paper, I provide a micro-foundation of the rigidity of collectively-bargained wages. This rigidity, in turn, amplifies the volatility of employment and labor market tightness over the business cycle. Using a calibration that matches the empirical regularities of the U.S., I show that labor market tightness is twice as volatile in a collective bargaining model than in an individual bargaining model. Therefore, accounting for collective wage bargaining greatly increases the performance of the search and matching model and partially addresses Shimer's (2005) critique that basic search and matching models are unable to capture the strong procyclicality of labor market tightness. This improvement is expected to be more substantial in European countries, where the union coverage often exceeds $80 \%$, than in the U.S., where the union coverage is currently approximately $10-15 \%$.

This paper also connects labor market volatility to the degree of coordination in collective wage bargaining. Indeed, the model accommodates a wage negotiation process that takes place at both the firm level and the economy level. Under collective wage-bargaining at the firm level, when a multitude of unions bargain with a continuum of firms, each union is too small to influence the market and, in particular, the vacancy filling rate. On the opposite, when wages are collectively bargained at the economy level, between a representative firm and a representative union, the representative union internalizes the positive wage effect on the vacancy-filling rate and is therefore more favorable towards pushing for higher wages. The countercyclicality of the worker share is dampened and this mechanism therefore suggests that wage rigidity decreases with the degree of centralization in collective wage bargaining.

Finally, this paper also addresses a large literature on the "insider-outsider" theory of wages and unemployment. ${ }^{4}$ This approach places market power into the hands of employed workers (insiders). In the present setting, employed workers under collective bargaining derive their market power from both the presence of search frictions and union representation. If unions were to be run by insiders only, the unions' utility would be a sole function of wages, and unions would raise wages to their maximum, similarly to an individual wage bargaining. As soon as unions put some weight on outsiders, employment enters the unions' utility function which brings unions to trade between wages and employment and to curb their wage demands. When the labor market is tight, the proportion of insiders to outsiders in unions is high, and insiders gain ability to impose their interests to the detriment of outsiders who suffer from a low job finding rate. The opposite occurs when the labor market is slack. Moreover, the model predicts that, when allowing unions to factor in the negative consequences of their wage demands on future employment opportunities and future worker surpluses, unions make more aggressive wage demands and the fluctuations in

\footnotetext{
${ }^{4}$ See for example Lindbeck and Snower (1986), Lindbeck and Snower (1989) and Blanchard and Summers (1986).
} 
the worker share are dampened.

The present model provides a convenient framework for analyzing the role of unions in shaping the volatility of wages and employment. In this sense, my paper is related to a small literature that studies the business cycle in settings that depart from perfect competition in the labor market. Mattesini and Rossi (2009) and Faia and Rossi (2013) analyze optimal monetary policy rules in a unionized or dual labor market economy, whereas Zanetti (2007) develops a DSGE model with the addition of a unionized labor market to analyze the macroeconomic responses to demand and supply shocks. In these three papers, unions dampen wage dynamics because union wages are assumed to depend on either exogenous union reservation wages or past wages, two assumptions that creates ad hoc wage rigidity. ${ }^{5}$ These assumptions and features are unsatisfactory if one wishes to identify the sources of union wage rigidity. Moreover, none of these studies integrates trade unions into a search and matching framework, which is yet a natural way of modeling the objective function for unions, from which the union wage and the endogenous worker share is derived, and allows for a clear comparison between individual and collective wage bargaining. Furthermore, the search and matching framework enables me to unveil a new mechanism of wage rigidity for collectively bargained wages and to give a novel perspective on the behavior of trade unions over the business cycle and on the cyclical properties of employment and labor market tightness. Similar to this paper, Alvarez and Shimer (2014) and Krusell and Rudanko (2012) introduce unions into a search model but their focus differs. Alvarez and Shimer (2014) analyze how unions, by imposing a minimum wage, affect both unemployment and the wage distribution. Krusell and Rudanko (2012) integrate monopoly unions into a search and matching framework to document the endogenous rigidity of wages that arises when wages are collectively bargained. Their analysis focuses on the welfare effect of a monopoly union, while I mainly study how trade unions affect the volatility of the labor market, disentangling the different channels through which collective bargaining affects the cyclical properties of wages, labor market tightness and employment. Moreover, monopoly unions represent a special case of my analysis, as I allow the union to bargain with firms regarding wages. This setting enables me to examine how a change in the union's bargaining process modifies labor market volatilities.

The paper proceeds as follows. The next section presents the collective wage bargaining and the equilibrium equations. I also provide a comparison of the wage formation and hiring processes with a standard individual Nash bargaining setting. Section 3 focuses on the model's properties: the countercyclical worker share that yields wage rigidity, and the countercyclical union wage premium. Section 4 quantitatively analyzes the dynamic behavior of the model for disturbances (productivity shocks). Section 5 concludes.

\footnotetext{
${ }^{5}$ In Mattesini and Rossi (2009), union wages are totally acyclical due to the additional assumption of a Stone-Geary utility function of the union.
} 


\section{The Model}

\subsection{The Environment}

\subsubsection{Collective vs. Individual Wage Bargaining}

In this paper, I compare the optimality conditions and business cycle features of the labor market under collective versus individual wage bargaining. In the benchmark case, characterized by individual wage bargaining, employers and employees agree on wages through a bilateral Nash bargaining process. In the case of collective wage bargaining, I assume that unions negotiate wages with firms on behalf of their members. The dynamic model that I develop accommodates both firm-level and economy-wide wage negotiations. I analyze individual and collective wage-setting process in isolation and by doing so, I implicitly assume a perfect segmentation of the labor market, i.e. workers are divided across a union and a non-union labor market, and barriers prevent free movement. ${ }^{6}$

\subsubsection{Timing}

Time is discrete. At the beginning of each period, the level of aggregate productivity is revealed and a fraction $\lambda$ of existing matches exogenously separate. Next, the matching process occurs. Because of search frictions, a fraction of unemployed workers and firms actually form a match during each period. The number of new matches in period $t, m_{t}$, is determined through a matching function that is increasing in both the number of unemployed workers, $u_{t}$, and the number of vacancies, $v_{t}: m_{t}=\sigma_{m} u_{t}{ }^{\sigma_{u}} v_{t}{ }^{1-\sigma_{u}}$ where $\sigma_{m}$ represents the efficiency of the matching process. At the end of the period, production occurs with a level of employment $n_{t}$, and salaries $w_{t}$ and unemployment benefits $b$ are paid. In this framework, firms react to productivity shocks by adjusting vacancies and newly employed workers start producing within the hiring period.

The two wage bargaining structures differ in the point in time at which wages are negotiated. Under individual wage bargaining, by the very nature of individual processing, wages are negotiated once each firm-worker pair is formed. Firms rationally anticipate the outcome of wage negotiations when they decide upon the number of vacancies to post. Under collective bargaining, I assume a right-to-manage timing based on a sequence à la Stackelberg, where unions first bargain with firms over wages and firms then respond by unilaterally determining vacancies. This timing contrasts with that adopted in the search and matching literature, but reflects the common practice both in both the trade union literature and studies incorporating trade unions into search and

\footnotetext{
${ }^{6}$ This assumption parallels the labor market segmentation into a unionized primary sector and a secondary competitive sector presented by MacDonald and Solow (1985). Moreover, in a model with homogenous workers, the assumption of labor market segmentation is in line with the sluggishness of the excess coverage rate (Cahuc and Zylberberg (2004)), which indicates that the division of workers into the union and non-union labor markets can be considered fixed in the short-run.
} 
matching frameworks (see Pissarides (1986), Mortensen and Pissarides (1999), and Delacroix (2006)).

\subsubsection{Stocks and Flows}

The labor force is homogeneous and normalized to one. The end-of-period employment $n_{t}$ evolves according to the following dynamics:

$$
n_{t}=1-u_{t}+m_{t}
$$

whereas the number of unemployed workers at the beginning of period $t$ evolves as:

$$
u_{t}=1-(1-\lambda) n_{t-1}
$$

\subsection{Vacancy Posting Decision under Collective Bargaining}

Firms are assumed to be sufficiently large to ensure that by the law of large numbers, the fraction of vacancies filled in each firm is equal to the vacancy filling rate: $q_{t}\left(\theta_{t}\right)=\frac{m_{t}}{v_{t}}$ where $\theta_{t}=\frac{v_{t}}{u_{t}}$ represents the labor market tightness. Aggregate productivity, denoted by $z_{t}$, follows an $A R(1)$ process. Given that firms are identical, I focus on a representative firm whose output is given by $y_{t}=z_{t} n_{t}$. The firms' costs consist of the wage and the vacancy posting cost ( $c$ per vacancy).

The number of posted vacancies maximizes the profit value function:

$$
\begin{aligned}
& \max _{v_{t}} F_{t}\left(n_{t}\right)=z_{t} n_{t}-w_{t} n_{t}-c v_{t}+E_{t} \beta F_{t+1}\left(n_{t+1}\right) \\
& \text { s.t. } n_{t}=(1-\lambda) n_{t-1}+q_{t} v_{t}
\end{aligned}
$$

where $\beta$ is the discount factor. The first-order condition is given by: ${ }^{7}$

$$
\frac{\partial F_{t}}{\partial v_{t}}=z_{t} q_{t}-w_{t} q_{t}-c+E_{t} \beta \frac{\partial F_{t+1}}{\partial n_{t}} q_{t}=0
$$

Applying the envelope condition to Equation 3 leads to:

$$
\frac{\partial F_{t}}{\partial n_{t-1}}=(1-\lambda) \frac{c}{q_{t}}
$$

Plugging Equation (4) into Equation (3), I obtain the job creation equation:

$$
\frac{c}{q_{t}}=z_{t}-w_{t}+E_{t} \beta(1-\lambda) \frac{c}{q_{t+1}}
$$

Because the job creation curve obtained under individual wage bargaining is a standard result in the search and matching literature, I succinctly derive it in

\footnotetext{
${ }^{7}$ Note that each individual firm and worker are too small to influence the market, so when they meet, they take the rest of the market as given.
} 
Appendix A.1 and I show that, with constant returns to scale in the production function, the job creation curve under collective wage bargaining, (5), is identical to that obtained under individual wage bargaining. The equation establishes that firms post vacancies up to the point at which the cost of posting a vacancy $c$ times the expected duration of the vacancy $\frac{1}{q_{t}}$ equals the contribution of the worker to the flow of profit plus the vacancy posting cost that the firm would save in $t+1$ if the match does not cease.

\subsection{Wage Negotiation under Collective Bargaining}

In this section, I focus on the wage bargaining process under collective wage bargaining, and I compare these optimality conditions with those for individual wage bargaining derived in Appendix A.2.

At the beginning of each period, unions and firms bargain over the wage. Subsequently, the firms unilaterally decide the number of vacancies to post based on the wage that has been previously negotiated. This right-to-manage model, which is in line with Nickell (1982) and Nickell and Andrews (1983), nests the special case of monopoly unions but allows for a more general assessment of how the unions' bargaining power affects wage volatility. ${ }^{8,9}$ Note that, in order to keep as simple a theoretical framework as possible, I do not introduce the possibility of overlapping contracts and leave the investigation of this issue open for future research. ${ }^{10}$

The Nash-bargained wage maximizes the product of the net gain of agreement for both parties.

\subsubsection{Collective Nash-Bargaining}

Net gain of agreement for unions. $W_{t}$ and $U_{t}$ denote the present values of being employed and being unemployed at the end of period $t$, respectively:

$$
\begin{aligned}
W_{t} & =w_{t}+E_{t} \beta\left[\left(1-\lambda+\lambda p_{t+1}\right) W_{t+1}+\lambda\left(1-p_{t+1}\right) U_{t+1}\right] \\
U_{t} & =b+E_{t} \beta\left[p_{t+1} W_{t+1}+\left(1-p_{t+1}\right) U_{t+1}\right]
\end{aligned}
$$

where $p_{t}=\frac{m_{t}}{u_{t}}$ is the job finding rate.

Unions are concerned with the welfare of their members, who are either employed or unemployed. At the time of bargaining, $1-u_{t}$ workers are employed, and all these workers will reach the payoff $W_{t}$ with certainty at the

\footnotetext{
${ }^{8}$ See Zanetti (2011), Mattesini and Rossi (2009), and Faia and Rossi (2013) for models with monopoly unions.

${ }^{9}$ Right-to-manage bargained wages are not Pareto efficient. Efficient contracts can be obtained if firms and unions were to bargain simultaneously over wages and employment, as shown by Leontief (1946). However, as argued by Calmfors and Horn (1986) and Oswald (1993), negotiations generally do not include employment explicitly.

${ }^{10} \mathrm{~A}$ plausible setting would be to have a Calvo-type staggered wage negotiation and trade unions that bargain over the duration of the wage contracts. Potentially, depending on the unions' utility function, such a framework could also generate endogenous wage rigidity.
} 
end of the period; by contrast, $u_{t}$ workers are unemployed, and a fraction $p_{t}$ of these workers will form a match and obtain the associated payoff $W_{t}$, with the remaining $1-p_{t}$ reaching the level of utility $U_{t}$. The unions' utility $\Omega_{t}$ is assumed to be the sum of the utility levels of their members:

$$
\begin{aligned}
& \Omega_{t}=\left(1-u_{t}\right) W_{t}+u_{t}\left[p_{t} W_{t}+\left(1-p_{t}\right) U_{t}\right] \\
& \Omega_{t}=n_{t}\left(W_{t}-U_{t}\right)+U_{t}
\end{aligned}
$$

Because all workers would be unemployed if the wage negotiation fails, the workers' fall back utility is $U_{t}$. Hence, the unions' net value of agreement is $n_{t}\left(W_{t}-U_{t}\right) .{ }^{11}$ Under the assumptions that workers and firms are homogenous, the value of employment for the marginal worker is identical among workers. Moreover, under constant returns to scale in the production function, the wage rate is independent of the employment level, and the welfare values $W_{t}$ and $U_{t}$ represent the employment and unemployment values, respectively, of both the marginal and average worker. Therefore, $W_{t}-U_{t}$ can be interpreted as the average worker's surplus and $n_{t}\left(W_{t}-U_{t}\right)$ as the total surplus of the workers.

This utilitarian specification, in line with MacDonald and Solow (1981) and Oswald (1982), is common in the trade union literature (see Calmfors (1982), Sampson (1983), Kidd and Oswald (1987), and Pissarides (1986), among others). First, this specification allows for an immediate comparison of the workers' objectives across wage bargaining processes. Workers who individually bargain over their wage seek to maximize their own surplus $W_{t}-U_{t}$ without considering how the bargain affects employment. In comparison, when negotiating with firms, unions aim at maximizing the sum of the workers' surpluses, $n_{t}\left(W_{t}-U_{t}\right)$. Both workers and unions foresee that their demands affect the firms' hiring decision. However, the specific feature of collective bargaining is that when negotiating wages, unions internalize the employer response to the wage bargain, as they seek to maximize the individual surplus of a match and the proportion of workers receiving this surplus. Second, the search and matching framework provides a natural way to model the workers' fall back utility $U_{t}$, which is not fixed over time but fluctuates with the expected evolution of market tightness. Third, in contrast with Stone-Geary utility functions, the unions' objective is directly derived from the union members' preferences. Therefore, the unions' utility specification, as described by Equation (8), allows for political considerations. Indeed, I will show that employment and wages do not have fixed weights in the unions' utility function and that, consequently, the relative importance that unions assign to these two issues endogenously fluctuates over the business cycle.

Net gain of agreement for firms. If the collective bargaining process is successful and if a wage agreement is reached, each firm obtains an end-ofperiod profit $F_{t}$, which includes the vacancy filling costs that are not sunk

\footnotetext{
${ }^{11}$ Given that the surplus of unemployed workers is equal to zero, the same net value of agreement is obtained if the union is assumed to be concerned only with the welfare of the workers who are employed at the end of the period.
} 
at the time of the bargaining. ${ }^{12}$ Moreover, because firms would not find any nonunion workers to fill vacancies if the bargaining fails, the firms' fall back payoff is zero. Therefore, the net gain of agreement for the firms is equal to $F_{t}$. As I show in Appendix B, the firms' profit can be written as a function of $J_{t}$, which denotes the firms' ex-post employment value of both the marginal and the average match, i.e., once the vacancy filling costs have been sunk:

$$
F_{t}=n_{t} J_{t}-c v_{t}
$$

where $J_{t}=z_{t}-w_{t}+E_{t} \beta(1-\lambda) J_{t+1}$.

\subsubsection{Wage Equation under Firm-Level Wage Negotiation}

I first derive the wage equation obtained when wages are collectively negotiated at each firm level. Equation (8) shows that the unions' utility depends on both wages and employment. High wages increase the individual worker's surplus, but because the job creation curve is downward sloping, high wages also reduce the firms' incentive to post vacancies and therefore lower employment: $\Omega_{t}=$ $\Omega_{t}\left(w_{t}, n_{t}\left(w_{t}\right)\right)$ with $\Omega_{w}^{\prime}>0, \Omega_{n}^{\prime}>0$, and $n_{w}^{\prime}<0$. The firms' labor demand function therefore embodies the trade-off faced by unions and constrains the unions' maximization problem. ${ }^{13}$ Moreover, when wages are negotiated at the firm-level, unions do not internalize the effect of wages on the vacancy-filling rate, as each union is too small to influence the market. Therefore, unions factor in the negative impact of wages on vacancies, but discard the wage effect on the vacancy-filling rate.

$$
\begin{aligned}
& \max _{w_{t}}\left[n_{t}\left(W_{t}-U_{t}\right)\right]^{\eta^{C}}\left[F_{t}\right]^{1-\eta^{C}} \\
& \text { s.t. job creation curve: } \frac{c}{q_{t}}=z_{t}-w_{t}+E_{t} \beta(1-\lambda) \frac{c}{q_{t+1}}
\end{aligned}
$$

where $\eta^{C}$ is the union's bargaining power. ${ }^{14}$

In Table 1, I report two results: i) the equilibrium condition for the worker share of the total surplus, $\tilde{\eta}_{t}$, that results from the first-order condition; and ii) the wage curve that derives from this equilibrium condition (see Appendices

\footnotetext{
${ }^{12}$ For this reason, the vacancy filling costs must be taken into account in the expected profit. Hence, the differences in the wage equations across wage-setting processes stem from both the difference in the level at which the wage bargaining occurs (individualized bargaining vs. collective bargaining) and the difference in timing (ex-ante wage bargaining in the union model vs. ex-post wage bargaining in the non-union model).

${ }^{13}$ This trade-off would disappear if the vacancy posting decision was made before the wage bargaining, and both wage-setting processes would lead to the same equilibrium. Indeed, if vacancies were posted ex-ante, the hiring decision would be based on the expected, or promised, wage level. Yet, the union cannot credibly announce that it will moderate the wage rate to promote hiring. Indeed, once the vacancies have been posted, the union would deviate from its announcement and push the wage to the highest possible level.

${ }^{14}$ For an empirical test of this maximization problem, see Dertouzos and Pencavel (1981).
} 
C.1 and C.3). Moreover, to compare the two wage-setting processes, I indicate the optimal worker share and the wage curve obtained under individual wage bargaining (see Appendices A.2 and A.2). ${ }^{15}$

When wages are individually bargained, the optimality condition states that the worker share of the total surplus equals the workers' bargaining power. In contrast, when wages are collectively bargained, the optimal worker share, $\tilde{\eta}_{t}$, is equal to the unions' bargaining power, $\eta$, multiplied by a second term that is endogenous and smaller than one. Regarding the wage curve, two comments are in order. First, the structure of the wage curve is identical across wage-setting processes, as both bargaining sets are bounded by the same wage levels: $z_{t}+$ $E_{t} \beta(1-\lambda) c \theta_{t+1}$ and $b$. Indeed, the third term on the right side of Equation (10), $\Theta_{t}$, which indicates how the expected evolution of the worker share affects the workers' wage, becomes negligible as the model's persistence increases. Second, because the worker share, $\tilde{\eta}_{t}$, is endogenous under collective wage bargaining, the sharing rule does not allocate a constant proportion of the bargaining set to the worker and the firm. Consequently, the fluctuations in the wage rate stem from two distinct sources: the fluctuations of the total surplus and the fluctuations of the worker share. This crucial result is the focus of Section 3.1.

\subsubsection{Wage Equation with Economy-Wide Wage Negotiation}

When wage bargaining is co-ordinated through economy-wide agreements, the collective bargain that takes place between an employer association and one "recognized" union translates in our framework into a bargaining process between a representative firm and a representative union. Because of the broad impact of the negotiated wage, the representative union internalizes the wage effect on both vacancy posting and the vacancy-filling rate. As a result, employment is less sensitive to wage changes, as the negative wage effect on vacancies is partially offset by the positive wage effect on the vacancy-filling rate.

The worker share of the total surplus and the wage curve are shown on Table $1{ }^{16}$ Equation (14) shows that the worker share $\tilde{\eta}_{t}$ is less cyclical than in the case of firm-level collective bargaining. Section 4.2.2 will compare the impulse responses to productivity shocks for these two levels of wage bargaining.

\section{The Model's Properties}

In this section, I illustrate the mechanism through which wage rigidity endogenously arises under collective wage bargaining. I analyze the degree of wage rigidity based on how wages fluctuate when the economy experiences a productivity shock. Because the model's properties are qualitatively similar

\footnotetext{
${ }^{15}$ To facilitate the comparison with the case of individual wage bargaining, I express the worker share of the ex-post total surplus associated with a single worker-firm match ("ex-post" means regardless of the vacancy posting cost).

${ }^{16}$ See Appendices C.3 and C.2 for the derivations.
} 
Table 1: Worker Share and Wage Curve

Individual wage bargaining

$$
\frac{W_{t}-U_{t}}{W_{t}-U_{t}+J_{t}}=\eta^{I} \quad w_{t}=\eta^{I}\left[z_{t}+E_{t} \beta(1-\lambda) c \theta_{t+1}\right]+\left(1-\eta^{I}\right) b
$$

Collective wage bargaining - Firm-level bargaining

$$
\begin{array}{ccc} 
& \frac{W_{t}-U_{t}}{W_{t}-U_{t}+J_{t}}=\tilde{\eta}_{t} \quad(9) & w_{t}=\tilde{\eta}_{t}\left[z_{t}+E_{t} \beta(1-\lambda) c \theta_{t+1}\right]+\left(1-\tilde{\eta}_{t}\right) b-\Theta_{t} \\
\text { where } \quad \tilde{\eta}_{t}=\eta^{C} \frac{\sigma_{u}}{\sigma_{u}+\eta^{C} \frac{m_{t}}{n_{t}}} \quad \text { (11) } & \text { where } \Theta_{t}=E_{t} \beta(1-\lambda)\left(1-p_{t+1}\right) \frac{c}{q_{t+1}} \frac{\tilde{\eta}_{t+1}-\tilde{\eta}_{t}}{1-\tilde{\eta}_{t+1}}
\end{array}
$$

Collective wage bargaining - Economy-wide bargaining

$$
\frac{W_{t}-U_{t}}{W_{t}-U_{t}+J_{t}}=\tilde{\eta}_{t}
$$

where $\quad \tilde{\eta}_{t}=\eta^{C} \frac{\sigma_{u}}{\sigma_{u}+\eta^{C}\left(1-\sigma_{u}\right) \frac{m_{t}}{n_{t}}}$

$$
w_{t}=\tilde{\eta}_{t}\left[z_{t}+E_{t} \beta(1-\lambda) c \theta_{t+1}\right]+\left(1-\tilde{\eta}_{t}\right) b-\Theta_{t}
$$

$$
\text { where } \Theta_{t}=E_{t} \beta(1-\lambda)\left(1-p_{t+1}\right) \frac{c}{q_{t+1}} \frac{\tilde{\eta}_{t+1}-\tilde{\eta}_{t}}{1-\tilde{\eta}_{t+1}}
$$

Note: $\eta^{C}$ and $\eta^{I}$ denote the union's bargaining power (under collective wage bargaining) and the workers' bargaining power (under individual wage bargaining), respectively.

for firm-level and economy-wide wage negotiations, I can use either of the two sets on results to illustrate the mechanisms at play, and this section focuses on economy-wide wage negotiation. I will disentangle the two levels of wage negotiation in Section 4 in which I carry out a quantitative assessment of the model.

\subsection{Countercyclical Worker Share}

To better comprehend the properties of the worker share, I express Equation (14) as a function of the beginning-of-period unemployment level, $u_{t}$, and the out-of-unemployment probability, $p_{t}$. For

$$
\tilde{\eta}_{t}=\eta^{C} \frac{\sigma_{u}\left(\frac{1}{u_{t}}-1+p_{t}\right)}{\sigma_{u}\left(\frac{1}{u_{t}}-1\right)+\left(\eta^{C}\left(1-\sigma_{u}\right)+\sigma_{u}\right) p_{t}}
$$

where the following properties hold (see Appendix C.4):

$$
\frac{\partial \tilde{\eta}_{t}}{\partial p_{t}}<0 \quad \frac{\partial \tilde{\eta}_{t}}{\partial u_{t}}<0
$$


The worker share is decreasing in the job-finding rate. Indeed, when the labor market becomes tighter and unemployed workers face a higher probability of finding a job, unions have a higher incentive to foster employment. Unions are therefore willing to hold back wages by lowering the worker share to encourage firms to post vacancies. Moreover, as unions are prone to prioritizing employment when unemployment is high, the worker share is also decreasing in the beginning-of-period unemployment level, a finding that is consistent with the existing empirical literature. ${ }^{17}$ On impact, given that the beginning-of-period unemployment level is predetermined, a productivity shock affects the worker share solely through its effect on the job-finding rate. Consequently, the worker share is countercyclical.

Examining the unions' maximization problem provides a deeper understanding of the countercyclical property of the worker share. The unions' utility function, Equation (8), is increasing in both wages and employment, and the marginal rate of substitution (MRS) between them indicates the relative value that unions assign to wages and employment. When the MRS of wages for employment is high (low), unions are considered wage (employment) oriented. Through its impact on wages and employment, a productivity shock alters the unions' MRS, and therefore, the trade-off unions make between wages and employment varies over the business cycle. The extent to which the MRS increases depends on the relative increase in wages compared with the increase in employment. A larger increase in wages compared to the increase in employment is associated with a lower marginal utility of wages and a decrease in the MRS. In this model, the wage rate reacts relatively more than the employment level, a result that is common in the search and matching literature. Indeed, the vacancy posting decision is motivated by the difference between the level of productivity and the wage rate, and the reaction of employment is smoother than that of the wage rate. ${ }^{18}$ Consequently, we obtain:

$$
M R S_{w_{t}, n_{t}}=-\frac{\partial n_{t}}{\partial w_{t}}=\frac{\frac{\partial \Omega_{t}}{\partial w_{t}}}{\frac{\partial \Omega_{t}}{\partial n_{t}}}=\frac{1-\eta^{C}}{c \eta^{C}} \frac{\partial m_{t}}{\partial z_{t}}\left[m_{t}-\sigma_{u}\left(n_{t}+m_{t}\right)\right]<0
$$

under standard calibration. See Appendix C.5 for the full derivation.

After the shock, the decrease in the MRS means that an additional increase in the employment level provides a higher level of utility than that in the previous period, relative to an additional increase in the wage rate. Therefore, the unions' preferences shift toward employment. This shift in preferences explains why unions are willing to lower the worker share to stimulate employment. Indeed, if the worker share were fixed, the wage rate would increase beyond its optimal level and would hinder vacancy postings.

Starting from the first period after the productivity shock, an additional (and opposite) mechanism is at play. A productivity shock occurring in period $t$

\footnotetext{
${ }^{17}$ See Aronsson, Löfgren, and Wikström (1993), Campbell (1997), and Calmfors, Booth, Burda, Checchi, Naylor, and Visser (2001).

${ }^{18}$ This mechanism embodies Shimer's critique. See Shimer (2005).
} 
affects the composition of unions, i.e., the proportion of (un)employed workers, from period $t+1$ onward. As stated in Equation (15), the worker share is negatively correlated with the beginning-of-period unemployment level, and this negative correlation opens a second channel through which shocks affect wage bargaining. Indeed, the heterogeneity of the unions' members introduces political considerations and reflects the internal conflict within the unions. As the positive shock propagates into the economy and lowers the proportion of unemployed workers, unions become more willing to exert upward pressure on wages by seizing a large portion of the total surplus.

Consequently, the unions' preferences and the consequent worker share fluctuate along the business cycle in the following manner. When a positive productivity shock occurs, unions become, on impact, more employment oriented. This shift in preferences translates into a decrease in the worker share that endogenously creates wage rigidity. In the periods that follow, as employment increases and as the wage rate returns to its steady state value, the marginal utility of employment decreases and the marginal utility of the wage rate increases, leading to a decrease of the MRS of employment for wages. Unions therefore give higher importance to wages relative to employment as the shock propagates in the economy, entailing a rapid return of the worker share to its steady state level, a curtailment of the persistence of wages, and a raise in the persistence of employment.

\subsection{Wage Rigidity}

The wage curves, Equation (13), demonstrates that the wage rate is driven by two variables: the procyclical total match surplus and the countercyclical worker share. The fluctuation of the worker share, which is constant under individual wage bargaining, is at the core of the wage rigidity mechanism under collective bargaining. Indeed, the dynamics of the worker share partially counteracts the dynamics of the total surplus and, consequently, dampens the wage fluctuations.

My comments are twofold. First, the current model provides a microfoundation for wage rigidity. Collectively bargained wages are less responsive to the business cycle because of the countercyclical property of the worker share, a property that directly results from the unions' maximization problem. Second, the nature of the wage rigidity observed here contrasts with that observed in a part of the literature that models either constant wages or wages featuring a backward-looking component, often with the aim of amplifying the volatility of unemployment and vacancies and thus responding to Shimer's critique. For instance, Hall (2005) and Shimer (2004) assume that wages do not fluctuate with the business cycle and that they are set at a constant socially acceptable level. In Krause and Lubik (2007), the wage is a weighted average of the Nash bargained wage and a wage norm. Gertler and Trigari (2009) introduce a staggered wagesetting, in which a certain proportion of the contracts are renegotiated during each period. In Blanchard and Gali (2007), Christoffel and Linzert (2010), and Shimer (2010), the wage is a weighted average of the past wage level and a 
current equilibrium wage level. ${ }^{19}$ In the present paper, the wage rate fluctuates with the current productivity level, and it is not an explicit function of its past value, i.e., it is not a state variable.

\subsection{Countercyclical Union Wage Premium}

The cyclical properties of the union wage premium directly result from the relative rigidity of collectively bargained wages. Indeed, because individually bargained wages are more cyclical than collectively bargained wages, the model predicts that the union wage premium increases during downturns and dwindles during upturns.

\section{Quantitative Assessment of the Model}

In this section, I investigate the quantitative properties of the model by studying the impulse responses of the labor market to a positive productivity shock. To do so, I consider a log-linear approximation of the equilibrium conditions as stated in Appendix C.6.

\subsection{Calibration}

The calibration of the model is described in Table 2. To facilitate the comparison between the two wage-setting processes and to identify the specific features of collective wage bargaining, I calibrate the individual wage bargaining model to match the empirical regularities of the U.S. and apply these calibrated parameter values to the collective wage bargaining model.

I interpret a period as a month. The discount factor is set to $0.99^{1 / 3}$, which corresponds to a yearly interest rate of $4 \%$, as commonly used in the macro$\mathrm{RBC}$ literature. I use quarterly data on real output and employment from the Bureau of Labor Statistics (BLS) Major Sector Productivity program over the 1955q1-2013q1 period. I construct labor productivity as the ratio of real output to the employment level and normalize the mean of the series to one. The productivity variable is then logged and de-trended by using an HP filter with a smoothing parameter of 1600 to isolate the cyclical component of the series. The log productivity level $z_{t}$ is assumed to follow an $A R(1)$ process: $\log \left(z_{t}\right)=\rho \log \left(z_{t-1}\right)+\epsilon_{t}$ where $\epsilon \sim N\left(0, \sigma^{2}\right)$. I fit an autoregressive time series model to the de-trended productivity data and obtain a persistence level of 0.7739 and a conditional standard deviation of 0.0082 . At a monthly frequency, the results are consistent with the setting $\rho=0.9181$ and $\sigma=0.0052$.

I target the probability $p$ that an unemployed worker forms a match within the period to $45 \%$, implying an unemployment period of approximately two months. This choice is consistent with Hall (2005) who estimates a monthly

\footnotetext{
${ }^{19}$ This current equilibrium wage level is the Nash bargained wage level in Christoffel and Linzert (2010) and Shimer (2010) and the MRS between consumption and leisure in Blanchard and Gali (2007).
} 
Table 2: Calibration

\begin{tabular}{lcc}
\hline Description & Parameter & Value \\
\hline Stochastic process for labor productivity & & 0.91812 \\
Autocorrelation & $\rho$ & 0.00515 \\
Standard deviation & $\sigma$ & 1 (normalization) \\
Mean labor productivity & $z$ & \\
& & \\
Common parameters & $\beta$ & $0.99^{1 / 3}$ \\
Discount rate & $\sigma_{u}$ & 0.5 \\
Elasticity of $m$ with respect to $u$ & $\bar{b}$ & 0.8 \\
Unemployment income & $\sigma_{m}$ & 0.6364 set to target $\theta=0.5$ \\
Efficiency of the matching process & $c$ & 0.3553 set to target $p=0.45$ \\
Vacancy posting cost & $\lambda$ & $0.1 / 3$ \\
Separation rate & & \\
& & \\
Individual wage bargaining & $\eta^{I}$ & 0.5 \\
Workers' bargaining power & & \\
Collective wage bargaining & $\eta^{C}$ & 0.9 \\
Unions' bargaining power & & \\
\hline
\end{tabular}

Note: Monthly calibration.

job finding rate of $0.48 \%$, and is in line with the estimate of this rate presented in Rogerson and Shimer (2011) for the U.S. for the 1948-2009 period. I also target the degree of labor market tightness $\theta$ to 0.5 , which is consistent with the estimate of 0.539 obtained by Hall (2005). I set the probability that each match ceases, $\lambda$, to $0.1 / 3$. This value is within the broadly accepted range of $8 \%-10 \%$ proposed by Hall (2005) and is similar to Shimer's (2005) exit probability estimate of $0.1 / 3$ for the U.S.. In the baseline model, the separation rates are identical across wage-setting processes; however, I check the robustness of the results by using an alternative calibration for $\lambda$ in the collective wage bargaining model (Section 4.2.3).

Regarding the matching function, two parameters must be discussed. First, the weight on unemployment $\sigma_{u}$, which represents both the elasticity of matches with respect to unemployment and the elasticity of the vacancy filling rate with respect to the labor market tightness, is set equal to 0.5 . This value is consistent with the range [0.5 - 0.7] proposed by Burda and Wyplosz (1994), based on estimations of the matching function for certain western European countries. ${ }^{20}$ Second, $\sigma_{m}$ is obtained from steady state calculations.

In contrast with the other parameters and targets, a debate regarding the

\footnotetext{
${ }^{20}$ See Petrongolo and Pissarides (2001) for a literature review on the estimation of the matching function's parameters.
} 
value of non-work activity, $\bar{b}=b / z$, exists. The paper by Hagedorn and Manovskii (2008) revised this debate by proposing a new estimate for this value of 0.95 . Indeed, in contrast to Shimer (2005) who restricts the value of nonwork activity to the unemployment benefits and sets $\bar{b}$ equal to 0.4, Hagedorn and Manovskii (2008) additionally integrate home production and the value of leisure. Delacroix (2006) also divides the unemployment income set at 0.6 into a home production of 0.3 and unemployment benefits of 0.3 . To ensure that my results are as plausible as possible, I choose an average value of 0.8 .

In line with the literature, I set the value of the worker's bargaining power to 0.5 to satisfy the Hosios condition and therefore to obtain an efficient decentralized equilibrium in the individual wage bargaining model. ${ }^{21}$ This value is suggested by Mortensen (1994) and Mortensen and Pissarides (1994) to ensure symmetry between workers and firms. The presence of unions is widely acknowledged to increase the workers' bargaining power. Indeed, firms' fall back payoff is lower under collective wage bargaining because they would not produce at all if disagreement arises. Given this observation, the unions' bargaining power must be fixed above 0.5. Additionally, if the unions' bargaining power were also equal to 0.5 , the steady state value of the wage rate obtained under collective wage bargaining would be lower than that obtained under individual wage bargaining. This result would contrast with the empirical literature that identifies a positive union wage premium..$^{22}$ I set the unions' bargaining power to 0.9 in the baseline calibration, and in Section 4.2.3, I check the implications of alternative values for the model's dynamics.

The steady state of the model is shown in Table 3. Because unions have higher bargaining power than individual workers, the steady state features a small but positive union wage premium. Because the firms' value of a filled vacancy decreases as the wage rate increases, vacancy postings are moderate in the collective wage bargaining model, rendering the labor market more slack and increasing both the unemployment rate and the unemployment duration.

Table 3: Steady State

\begin{tabular}{lcc}
\hline & Collective wage bargaining & Individual wage bargaining \\
\hline Wage & 0.995 & 0.985 \\
Vacancies & 0.012 & 0.036 \\
Unemployment rate & $17.1 \%$ & $7.1 \%$ \\
Unemployment duration & $6 \mathrm{~m}$. & $2.2 \mathrm{~m}$. \\
\hline
\end{tabular}

\footnotetext{
${ }^{21}$ See Hosios (1990).

${ }^{22}$ See for example Blanchflower and Bryson (2004).
} 


\subsection{Dynamics}

In this section, I first study the business cycle properties of the model by analyzing the simulated moments and the impulse response functions generated by the model. I set the economy-wide wage negotiation as the baseline level of negotiation and compare the impulse response functions with the ones obtained under firm-level wage negotiation. Next, I check the robustness of the results for alternative values of the unions' bargaining power and the union separation rate.

\subsubsection{Moments}

Table 4: Summary Statistics, Quarterly U.S. Data, 1955q1-2013q1

\begin{tabular}{lccccccc}
\hline & & $n$ & $u$ & $v$ & $\theta$ & $w$ & $z$ \\
\hline Standard deviation & & 0.016 & 0.120 & 0.135 & 0.249 & 0.009 & 0.013 \\
Autocorrelation & & 0.921 & 0.900 & 0.899 & 0.903 & 0.686 & 0.770 \\
\hline Correlation & $n$ & 1 & -0.939 & 0.842 & 0.8985 & 0.0062 & 0.0452 \\
& $u$ & & 1 & -0.904 & -0.964 & -0.099 & -0.227 \\
& $v$ & & & 1 & 0.982 & 0.162 & 0.411 \\
& $\theta$ & & & & 1 & 0.133 & 0.339 \\
& $w$ & & & & & 1 & 0.295 \\
& $z$ & & & & & & 1 \\
\hline
\end{tabular}

Notes: I construct labor productivity as the ratio of real output to the employment level. Real output is the real gross domestic product in the non-farm business sector as published by the Bureau of Economic Analysis of the U.S. Department of Commerce. Employment is nonfarm business employment taken from the Main Sector Productivity Costs program developed by BLS. Data on the unemployment level and rate are taken from the BLS Current Population Survey. Labor market tightness is constructed as the ratio of vacancies over unemployment, where the vacancy series is constructed by merging data from the Conference Board, before 1995, with data from Barnichon (2010), after 1995. Wages are real hourly compensation published by the BLS Main Sector Productivity Costs program. All series are logged and HP filtered with a smoothing parameter of 1600 .

Table 4 provides an overview of the time-series behavior of several labor market variables in the U.S. over the 1955-2013 period. Data on unemployment, wages, and employment are taken from the Main Sector Productivity Costs program and the Current Population Survey developed by the BLS. I construct the vacancy series by using Barnichon (2010)'s methodology. I use the Conference Board dataset until 1995 and substitute in the data constructed by Barnichon for the later period. I construct labor productivity by dividing the real output with the employment level, as explained in Section 4.1. I restrict my analysis to the behavior of the labor market at business cycle frequencies and abstract from factors that affect the long-run evolution of the labor market, such as changes in the education system or in demographics. Therefore, all variables are logged and de-trended by using an HP filter with a smoothing parameter of 1600 . 
Table 5: Simulated Moments - Individual Wage Bargaining

\begin{tabular}{|c|c|c|c|c|c|c|c|}
\hline & & $n$ & $u$ & $v$ & $\theta$ & $w$ & $z$ \\
\hline \multirow[t]{2}{*}{ Standard deviation } & & 0.0021 & 0.0512 & 0.0404 & 0.0624 & 0.0114 & 0.0127 \\
\hline & & $(0.0002)$ & $(0.0056)$ & $(0.0032)$ & $(0.0063)$ & $(0.0011)$ & $(0.0013)$ \\
\hline \multirow[t]{2}{*}{ Autocorrelation } & & 0.8517 & 0.8520 & 0.5317 & 0.7555 & 0.7555 & 0.7560 \\
\hline & & $(0.0294)$ & $(0.0295)$ & $(0.0724)$ & $(0.0456)$ & $(0.0457)$ & $(0.0458)$ \\
\hline \multirow[t]{11}{*}{ Correlation } & $n$ & 1 & -0.9994 & 0.8618 & 0.9303 & 0.9674 & 0.9297 \\
\hline & & & $(0.0002)$ & $(0.0239)$ & $(0.0150)$ & $(0.0056)$ & $(0.0149)$ \\
\hline & $u$ & & 1 & -0.8615 & -0.9301 & -0.9683 & -0.9303 \\
\hline & & & & $(0.0238)$ & $(0.0150)$ & $(0.0058)$ & $(0.0151)$ \\
\hline & $v$ & & & 1 & 0.9489 & 0.7904 & 0.9484 \\
\hline & & & & & $(0.0062)$ & $(0.0379)$ & $(0.0061)$ \\
\hline & $\theta$ & & & & 1 & 0.8311 & 0.9996 \\
\hline & & & & & & $(0.0327)$ & $(0.0001)$ \\
\hline & $w$ & & & & & 1 & 0.8315 \\
\hline & & & & & & & $(0.0329)$ \\
\hline & $z$ & & & & & & 1 \\
\hline
\end{tabular}

Notes: Simulated moments are average values over 200 simulations of a 182 period loglinearized model of individual wage bargaining. The standard errors are shown in parentheses. All variables are expressed in log-deviation from the steady state.

Tables 5 and 6 report the moments obtained by simulating the log-linearized models of individual and collective wage bargaining, respectively. Specifically, I simulate the log-linearized model with stochastic labor productivity and generate 996 data points. I drop the first 300 observations, and among the remaining data points, I maintain one of three observations. Thus, I obtain quarterly data points from simulating a monthly calibrated model. The number of remaining data points corresponds to the length of the 1955q1-2013q1 period. I repeat the simulation 200 times. The moments presented in the two tables are average values and standard errors across model-generated observations.

The first set of results concerns the volatility of the labor market. As Shimer (2005) notes, individually Nash-bargained wages feature excessive volatility that depresses the creation of vacancies. The standard deviations of employment and market tightness that characterize the individual wage bargaining model are eight and four times smaller, respectively, than the observed statistics. The simulated moments presented in Table 6 indicate that the volatility of the labor market is much larger when wages are collectively bargained than when wages are individually bargained. The standard deviations of employment, vacancies and market tightness are larger in the collective wage bargaining model than in the individual wage bargaining model, and the volatility of these variables increases as the union's bargaining power increases. For monopoly unions, characterized by a union bargaining power of one, the standard deviations of vacancies and market tightness exceed the observed values by $190 \%$ and $56 \%$, respectively. Therefore, by considering both types of wage bargaining, the simulated moments are closer to the observed labor market statistics. Indeed, 
Table 6: Simulated Moments - Collective Wage Bargaining

\begin{tabular}{|c|c|c|c|c|c|c|c|}
\hline$\eta=0.9$ & & $n$ & $u$ & $v$ & $\theta$ & $w$ & $z$ \\
\hline Standard deviation & & 0.0046 & 0.0270 & 0.0508 & 0.0653 & 0.0122 & 0.0127 \\
\hline Autocorrelation & & 0.9168 & 0.9169 & 0.5225 & 0.6946 & 0.7620 & 0.7440 \\
\hline \multirow[t]{6}{*}{ Correlation } & 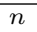 & 1 & -0.9997 & 0.7822 & 0.9143 & 0.8900 & 0.9411 \\
\hline & $u$ & & 1 & -0.7808 & -0.9133 & -0.8905 & -0.9408 \\
\hline & $v$ & & & 1 & 0.9600 & 0.7671 & 0.9305 \\
\hline & $\theta$ & & & & 1 & 0.8175 & 0.9956 \\
\hline & $w$ & & & & & 1 & 0.8207 \\
\hline & $z$ & & & & & & 1 \\
\hline$\eta=0.97$ & & $n$ & $u$ & $v$ & $\theta$ & $w$ & $z$ \\
\hline Standard deviation & & 0.0102 & 0.0246 & 0.1527 & 0.1576 & 0.0112 & 0.0127 \\
\hline Autocorrelation & & 0.8256 & 0.8257 & 0.0147 & 0.0842 & 0.8348 & 0.7440 \\
\hline \multirow[t]{6}{*}{ Correlation } & $n$ & 1 & -0.9996 & 0.4860 & 0.5866 & 0.9944 & 0.9041 \\
\hline & $u$ & & 1 & -0.4838 & -0.5845 & -0.9953 & -0.9039 \\
\hline & $v$ & & & 1 & 0.9904 & 0.4773 & 0.5416 \\
\hline & $\theta$ & & & & 1 & 0.5803 & 0.6525 \\
\hline & $w$ & & & & & 1 & 0.9140 \\
\hline & $z$ & & & & & & 1 \\
\hline$\eta=1$ & & $n$ & $u$ & $v$ & $\theta$ & $w$ & $z$ \\
\hline Standard deviation & & 0.0118 & 0.0274 & 0.3922 & 0.3890 & 0.0186 & 0.0127 \\
\hline Autocorrelation & & 0.6716 & 0.6688 & -0.1188 & -0.1005 & 0.2690 & 0.7440 \\
\hline \multirow[t]{6}{*}{ Correlation } & $n$ & 1 & -0.9996 & 0.2544 & 0.2991 & 0.3248 & 0.7659 \\
\hline & $u$ & & 1 & -0.2550 & -0.2997 & -0.3238 & -0.7652 \\
\hline & $v$ & & & 1 & 0.9981 & 0.0566 & 0.2582 \\
\hline & $\theta$ & & & & 1 & 0.0955 & 0.3179 \\
\hline & $w$ & & & & & 1 & 0.6266 \\
\hline & $z$ & & & & & & 1 \\
\hline
\end{tabular}

Notes: Simulated moments are average values over 200 simulations of a 182 period loglinearized model of collective wage bargaining. All variables are expressed in log-deviation from the steady state. The standard errors are not reported because the order of magnitude is very small $\left(10^{-14}\right)$.

averaging the standard deviations of the labor market tightness in both models, by using the percentage of union coverage in the U.S. as weights, yields a volatility of the labor market tightness of 0.121 , which is half of the observed volatility. ${ }^{23}$ In contrast, the individual wage bargaining model explains a quarter of the labor market tightness statistics. Therefore, accounting for collective wage bargaining greatly increases the performance of the model and partially addresses Shimer's critique.

The difference in labor market volatilities across models stems from the combined effect of two mechanisms. First, as explained in Section 3.2, the unions' behavior endogenously generates wage rigidity. Consequently, the firms' surplus and therefore vacancies are more cyclically sensitive. Because the countercyclical property of the worker share is at the core of this mechanism, I refer to it as the worker share effect of unions. Note that wages are more rigid when unions have strong bargaining power. To understand how the union bargaining power affects the worker share effect, I examine the log-linearized

\footnotetext{
${ }^{23}$ Over the $1977-2013$ period, the average union coverage equals $18 \%$. Source: unionstats.com
} 
equilibrium condition on the worker share:

$$
\hat{\tilde{\eta}}_{t}=-\left(\gamma\left(1-\lambda+\frac{\lambda}{p}\right)\right) \hat{u}_{t}-\left(\gamma\left(1-\sigma_{u}\right)(1-\lambda)\right) \hat{\theta}_{t}
$$

where $\gamma=\frac{\eta^{C}\left(1-\sigma_{u}\right) \lambda}{\eta^{C}\left(1-\sigma_{u}\right) \lambda+\sigma_{u}}$ and the hat operator denotes log-deviation from the steady state. Because $\gamma$ is increasing in $\eta^{C}$, the change in the worker share resulting from a change in the labor market tightness increases as the unions' bargaining power increases. Indeed, for high values of the unions' bargaining power, wages would be more volatile if the worker share were fixed. Therefore, a positive shock encourages unions to be even more employment-oriented and to substantially decrease the worker share. The positive shock thus leads to a strong impulse in vacancy creation and to large volatility in the labor market. Consequently, the worker share effect increases with the unions' bargaining power.

Second, because unions have stronger bargaining power than individual workers, the labor market is more volatile when wages are collectively bargained. As argued by Hagedorn and Manovskii (2008), the size of the percentage change in the firms' surplus in response to a shock generates the firms' incentive to post vacancies. Percentage changes are negatively correlated with the steady-state value of the firms' surplus. Therefore, through its effect on wages, a strong unions' bargaining power reduces the firms' surplus. Consequently, stronger union bargaining power is associated with larger percentage changes in the firms' surplus and a greater incentive for the firms to post vacancies. This mechanism builds on the difference in steady states that results from the difference in bargaining power between unions and workers. Hence, I refer to this mechanism as the steady-state effect of unions. By definition, I expect the steady-state effect of unions to increase with the unions' bargaining power. In the next section, the analysis of the impulse-response functions will enable me to quantitatively disentangle the worker share effect from the steady-state effect of unions on the labor market volatility.

Table 6 shows that the relationship between wage volatility and the unions' bargaining power is not linear. Such nonlinearity arises because, although wages are rigid on impact, they are also more persistent, as discussed in Section 3.1. The total effect on wage volatility depends on the relative strength of these two opposite forces. Here, the analysis of the impulse responses that will be conducted in the next section will allow me to observe the rigidity of wages on impact and their persistence over time.

Regarding the autocorrelations, I observe that employment, vacancies, and market tightness are less persistent for higher values of the unions' bargaining power but that the autocorrelation measures do not match the observed statistics.

Finally, regarding the empirical correlations, the negative correlation between unemployment and vacancies, i.e., the Beveridge curve, appears to be too strong in the individual bargaining model relative to the observed statistics. This correlation decreases, in absolute terms, in the collective bargaining model, 
suggesting that including collective bargaining in the analysis improves the fit of the model. The risk, however, is that the correlation will be undervalued if the weight on collective bargaining, e.g., the union coverage, is too large or if the unions' bargaining power is too high. Finally, the correlations between wages and the other labor market variables in the case of union monopoly indicate that considering collective wage bargaining brings the simulated moments closer to the data. In particular, wages are less correlated with the unemployment rate, market tightness, and labor productivity when wages are collectively bargaining than when wages are individually bargained. However, this result should be considered with caution because the relationship between the correlation values and the unions' bargaining power is not linear.

\subsubsection{Impulse Responses to Productivity}

Economy-wide wage negotiation. As explained in the previous section, the difference in labor market dynamics across the models is explained by both the worker share effect and the steady state effect of unions. To assess the relative importance of these two effects on the labor market dynamics, I introduce an intermediate case that is characterized by (a) individual wage bargaining and (b) high worker bargaining power such that the steady state is identical to the steady state prevailing in the collective wage bargaining model. Figure 1 shows the response of the labor market to a positive productivity shock of one standard deviation. The dynamics of the collective wage bargaining model is represented by the plain line. I also report the dynamics of the individual wage bargaining model (dashed line) and of the intermediate model (dotted line) to be able to quantitatively assess the relative importance of the two effects.

By construction, the difference between the dashed line (individual wage bargaining) and the dotted line (intermediate model) captures the steady-state effect of unions. As explained in the previous section, an increase in the bargaining power modifies the steady state and affects the dynamics of the model. Specifically, in the intermediate model, the strong bargaining power of the workers pushes wages up and, through this channel, reduces the firms' surplus, in the steady state. Consequently, when the economy experiences a positive productivity shock, the percentage change in the firms' surplus is larger, and so is the firms' incentive to post vacancies. Therefore, in the intermediate model, although wages show a greater reaction to the shock, employment is more volatile.

The worker share effect of unions entirely accounts for the gap between the plain line (collective wage bargaining) and the dotted line (intermediate model). This effect derives from the countercyclical worker share that characterizes collective wage bargaining. On impact, unions lower the worker share and, through this channel, slightly decreases the volatility of wages. Indeed, the dashed line lies below the dotted line, which indicates that collective wages are more rigid on impact. Because wages are less reactive to the shock, firms gain an extra surplus and react by posting more vacancies. Consequently, the reaction of labor market tightness and employment is stronger. As the shock propagates 
in the economy and as employment increases, more employed workers call for high-level wages, which results in a change in the unions' preferences. As unions become more wage-oriented, they progressively engage into a more aggressive wage policy by boosting the worker share, which slows down the wage reversion toward its steady-state level. Moreover, because the worker share effect increases the persistence of wages, the firms' surplus, the vacancies, and the employment rate feature less persistence.

Figure 1 shows that the worker share effect of unions almost entirely explains the extra volatility of labor market tightness featured in the collective wage bargaining model. Additionally, the worker share effect accounts for most of the extra volatility of employment in the first periods after the shock, and as the shock propagates into the economy, its relative importance decreases in favor of the steady-state effect of unions.

Firm-level wage negotiation. Figure 2 compares economy-wide collective wage bargaining with firm level wage bargaining. When unions are too small to influence the hiring rate, they abstract from the positive effect that wages have on the vacancy filling rate and overestimate the negative wage effect on employment. As a result, they are more reluctant to push for higher wages and the countercyclicality of the worker share is strengthened. Consequently, wages are more rigid and employment fluctuations are larger. This result therefore suggests that wage rigidity depends negatively on the degree of centralization of collective bargaining.

\subsubsection{Robustness}

The value of the unions' bargaining power. Given the lack of evidence for identifying the value of the unions' bargaining power, I analyze the response of the labor market under three possible values of $\eta^{C}: \eta^{C}=0.8, \eta^{C}=0.9$ (baseline calibration), and $\eta^{C}=1$ (monopoly union). Figure 3 shows how the worker share, wages, the labor market tightness, and the employment rate respond to a positive productivity shock. I observe that the worker share effect of unions increases as the unions' bargaining power increases. Indeed, although the worker share effect is negligible for low values of $\eta^{C}$, it is salient in the case of monopoly unions. For high values of the unions' bargaining power, wages would greatly increase if the worker share were fixed, and a positive shock therefore induces unions to prioritize employment. The consequent decrease in the worker share leads to a strong response of vacancy creation and labor market tightness. Therefore, this result confirms the theoretical prediction (Section 4.2.1) that the worker share effect increases with the unions' bargaining power.

The value of $\lambda$. The empirical literature presents evidence that the separation rate is lower in highly unionized sectors. ${ }^{24}$ To be in line with this strand of

\footnotetext{
${ }^{24}$ For example, Freeman (1980) shows that in the U.S., tenure is greater for workers who are covered by union contracts and that the probability of their match ceasing is lower. Knight and Latreille (2000) and Antcliff and Saundry (2009) find similar results for the U.K.
} 
research, I study the case in which the separation rate is $20 \%$ lower in the collective wage-bargaining model $\left(\lambda^{C}=0.08 / 3\right)$ compared with the individual wage bargaining model (in which I maintain $\lambda^{I}=0.1 / 3$ ).

As shown in Figure 4, the worker share effect is not substantially modified by the alternative calibration. The decrease in the separation rate dampens the volatility of the worker share; however the overall effect on the wage and employment dynamics is small. Furthermore, the alternative calibration modifies the steady state effect. When the exit rate is low, firms benefit from a larger surplus in the steady state, and a shock therefore leads to smaller percentage changes in the firms' surplus. Consequently, the firms' incentive to post vacancies is lower, which explains the moderate increase in employment.

\section{Extension: Insiders vs. Outsiders}

The unions' utility function presented in Equation 8 also uncovers the clash of interests between employed and unemployed workers and allows us to analyze the unions' strategy through the lens of the outsider-insider literature. Insiders, i.e. employed workers, push for higher wages because it directly increases their utility. Outsiders, i.e. unemployed workers, lobby for lower worker share, so as to give incentive to firms to post vacancies. Here, I open a new channel through which wages affect the workers' surplus. Specifically, workers, and therefore unions, now take into account the following mechanism: high wages, by lowering employment, trigger a higher unemployment rate next period that reduces the future probability for unemployed workers to find jobs and increases the future surplus of employed workers. Therefore, by lowering the future job-finding rate, an increase in wages greatly benefits insiders. Under this new assumption, the labor share is (See Appendix D for the derivation):

$$
\frac{W_{t}-U_{t}}{W_{t}-U_{t}+J_{t}}=\frac{\eta^{C} \sigma_{u}\left(1+\psi_{t}\right)}{\sigma_{u}+\eta^{C} \sigma_{u} \psi_{t}+\eta^{C}\left(1-\sigma_{u}\right) \frac{m_{t}}{n_{t}}}
$$

where $\psi_{t}=\beta(1-\lambda)^{2} \frac{\left(1-\sigma_{u}\right)^{2}}{\sigma_{u}} \frac{p_{t+1}}{u_{t+1}} \frac{m_{t}}{J_{t}}\left(W_{t+1}-U_{t+1}\right)$. This new channel increases the unions' marginal utility of wages and lowers the countercyclicality of the worker share. The impulse responses presented in Figure 5 confirm that, when unions take into account the wage effect on the future surplus of workers, the worker share is more rigid, wages are more cyclical, and employment's fluctuations are dampened.

\section{Concluding Remarks}

By modeling collective wage bargaining in a search and matching framework, I develop a tractable model of the labor market that enables me to investigate how labor unions affect labor market dynamics. In the traditional search and matching literature, wages typically fluctuate with the total match value. I 
show that when wages are collectively bargained, a second source of wage volatility arises: the worker share fluctuates countercyclically, dampening wage fluctuations. The model predicts that when the economy experiences a positive productivity shock, employment-oriented unions react by reducing the worker share and, hence, by moderating the wage increase. The model therefore explains and provides a micro-foundation of the rigidity of wages, and I show that this rigidity, in turn, amplifies the response of employment and labor market tightness. Moreover, I demonstrate the reversal of the unions' preference as the shock propagates in the economy and increases the employment level. The change in the composition of unions in favor of employed workers encourages unions to be more wage-oriented and to seize a larger portion of the total match surplus. Consequently, wages are more persistent when they are collectively bargained than when they are individually bargained. The dynamics of the labor market also results from the higher bargaining power of unions compared to the one of individual workers. The analysis of the impulse-response functions allows me to quantitatively assess the relative importance of these two effects. The results indicate that the countercyclical adjustment of the worker share is the main source of the additional volatility of the labor market in the collective wage bargaining model, and that this effect is larger when the unions' bargaining power is stronger.

The model presented in this paper represents an improvement over the current literature by bringing together two strands of research, as it improves our theoretical understanding of the sources of wage and employment volatility as well as the role of labor unions in shaping these volatilities. Moreover, including collective wage bargaining improves the fit of the search and matching model and partially addresses Shimer's critique. Finally, this paper provides a rationale for two empirical regularities: the observed countercyclicality of the union wage premium and the negative correlation between the unions' ability to raise wages and the level of unemployment. 


\section{References}

Alvarez, F., and R. Shimer (2014): "Unions and Unemployment," Working paper.

Antcliff, V., and R. Saundry (2009): "Accompaniment, Workplace Representation and Disciplinary Outcomes in British Workplaces - Just a Formality?," British Journal of Industrial Relations, 47(1), 100-121.

Aronsson, T., K.-G. Löfgren, and M. Wikström (1993): "Monopoly union versus efficient bargaining," European Journal of Political Economy, $9,357-370$.

Barnichon, R. (2010): "Building a composite Help-Wanted Index," Economics Letters, 109(3), 175-178.

Blanchard, O., and J. Gali (2007): "Real Wage Rigidities and the NewKeynesian Model," Journal of Money, Credit and Banking, 39(1).

Blanchard, O. J., and L. H. Summers (1986): "Hysteresis and the European Unemployment Problem," in NBER Macroeconomics Annual 1986, Volume 1, NBER Chapters, pp. 15-90. National Bureau of Economic Research, Inc.

Blanchflower, D. G., and A. Bryson (2004): "What Effect Do Unions Have on Wages Now and Would Freeman and Medoff Be Surprised?," Journal of Labor Research, 25(3), 383-414.

Burda, M., and C. Wyplosz (1994): "Gross worker and job flows in Europe," European Economic Review, 38, 1287-1315.

Cahuc, P., and E. Wasmer (2001): "Does Intrafirm Bargaining Matter In The Large Firm'S Matching Model?," Macroeconomic Dynamics, 5(05), 742-747.

Cahuc, P., And A. Zylberberg (2004): Labor Economics, vol. 1 of MIT Press Books. The MIT Press.

Calmfors, L. (1982): "Employment Policies, Wage Formation and Trade Union Behavior in a Small Open Economy," The Scandinavian Journal of Economics, (2).

Calmfors, L., A. Booth, M. Burda, D. Checchi, R. Naylor, and J. VissER (2001): "The Future of Collective Bargaining in Europe," in The Role of Unions in the Twenty-First Century, ed. by T. Boeri, A. Brugiavini, and L. Calmfors. Oxford.

Calmfors, L., and H. Horn (1986): "Employment Policies and Centralized Wage-Setting," Economica, 53(211), 281-302.

Campbell, C. M. I. (1997): "The variation in wage rigidity by occupation and union status in the U.S.," Oxford bulletin of economics and statistics, 59. 
Christoffel, K., and T. Linzert (2010): "The Role of Real Wage Rigidity and Labor Market Frictions for Inflation Persistence," Journal of Money, Credit and Banking, 42(7), 1435-1446.

Delacroix, A. (2006): "A multisectorial matching model of unions," Journal of Monetary Economics, 53, 573-596.

Dertouzos, J. N., and J. H. Pencavel (1981): "Wage and Employment Determinants under Trade Unionism: The International Typographical Union," NBER Working Papers 0570, National Bureau of Economic Research, Inc.

Du Caju, P., E. Gautier, D. Momferatou, and M. Ward-Warmedinger (2008): "Institutional features of wage bargaining in 23 European countries, the US and Japan," Working Paper Series 974, European Central Bank.

Faia, E., and L. Rossi (2013): "Union Power, Collective Bargaining, And Optimal Monetary Policy," Economic Inquiry, 51(1), 408-427.

Freeman, R., and J. L. Medoff (1984): in What do unions do?, ed. by N. Y. B. Books.

Freeman, R. B. (1980): "The Exit-Voice Tradeoff in the Labor Market: Unionism, Job Tenure, Quits," NBER Working Papers 0242, National Bureau of Economic Research, Inc.

Garibaldi, P., and G. L. Violante (2005): "The Employment Effects of Severance Payments with Wage Rigidities," Economic Journal, 115(506), 799832 .

Gertler, M., and A. Trigari (2009): "Unemployment Fluctuations with Staggered Nash Wage Bargaining," Journal of Political Economy, 117(1), 3886.

Hagedorn, M., and I. Manovskil (2008): "The Cyclical Behavior of Equilibrium Unemployment and Vacancies Revisited," American Economic Review, 98(4), 1692-1706.

Hall, R. E. (2005): "Employment Fluctuations with Equilibrium Wage Stickiness," American Economic Review, 95(1), 50-64.

Hosios, A. J. (1990): "On the Efficiency of Matching and Related Models of Search and Unemployment," Review of Economic Studies, 57(2), 279-98.

KidD, D. P., And A. J. Oswald (1987): "A Dynamic Model of Trade Union Behaviour," Economica, 54(215), 355-65.

Knight, K., and P. Latreille (2000): "Discipline, Dismissals and Complaints to Employment Tribunals," British Journal of Industrial Relations, 38(4), 533-555. 
Krause, M. U., And T. A. LubiK (2007): "The (ir)relevance of real wage rigidity in the New Keynesian model with search frictions," Journal of Monetary Economics, 54(3), 706-727.

Krusell, P., and L. Rudanko (2012): "Unions in a Frictional Labor Market," NBER Working Papers 18218, National Bureau of Economic Research, Inc.

Leontief, W. (1946): "The Pure Theory of the Garanteed Annual Wage Contract," The Journal of Political Economy, 54(1), 76-79.

Lindbeck, A., and D. J. Snower (1986): "Wage Setting, Unemployment, and Insider-Outsider Relations," American Economic Review, 76(2), 235-39.

Lindbeck, A., And D. J. SNower (1989): The Insider-Outsider Theory of Employment and Unemployment, vol. 1 of MIT Press Books. The MIT Press.

MacDonald, I., and R. Solow (1981): "Wage Bargaining and Employment," The American Economic Review, 71(5), 896-908.

(1985): "Wages and employment in a segmented labor market," The Quarterly Journal of Economics, 100(4), 1115-1141.

Mattesini, F., and L. Rossi (2009): "Optimal monetary policy in economies with dual labor markets," Journal of Economic Dynamics and Control, 33(7), $1469-1489$.

Mortensen, D., and C. Pissarides (1994): "Job Creation and Job Destruction in the Theory of Unemployment," Review of Economic Studies, 61, 397415 .

Mortensen, D. T. (1994): "The cyclical behavior of job and worker flows," Journal of Economic Dynamics and Control, 18(6), 1121-1142.

Mortensen, D. T., and C. A. Pissarides (1999): "New developments in models of search in the labor market," in Handbook of Labor Economics, ed. by O. Ashenfelter, and D. Card, vol. 3 of Handbook of Labor Economics, chap. 39, pp. 2567-2627. Elsevier.

Nickell, S. (1982): "A bargaining model of the Phillips curve," LSE Centre for Labour Economics Discussion Paper.

Nickell, S. J., And M. Andrews (1983): "Unions, Real Wages and Employment in Britain 1951-79," Oxford Economic Papers, 35(0), 183-206.

Oswald, A. J. (1982): "The Microeconomic Theory of the Trade Union," Economic Journal, 92(367), 576-95.

Oswald, A. J. (1993): "Efficient contracts are on the labour demand curve : Theory and facts," Labour Economics, 1(1), 85-113. 
Petrongolo, B., and C. A. Pissarides (2001): "Looking into the Black Box: A Survey of the Matching Function," Journal of Economic Literature, 39(2), $390-431$.

Pissarides, C. A. (1986): "Trade Unions and the Efficiency of the Natural Rate of Unemployment," Journal of Labor Economics, 4(4), 582-95.

Rogerson, R., and R. Shimer (2011): Search in Macroeconomic Models of the Labor Marketvol. 4 of Handbook of Labor Economics, chap. 7, p. Pages: 61. Elsevier.

Sampson, A. A. (1983): "Employment Policy in a Model with a Rational Trade Union," Economic Journal, 93(37), 297-311.

Shimer, R. (2004): "The Consequences of Rigid Wages in Search Models," NBER Working Papers 10326, National Bureau of Economic Research, Inc.

Shimer, R. (2005): "The Cyclical Behavior of Equilibrium Unemployment, Vacancies and Wages: Evidence and Theory," American Economic Review, 95(1), 25-49.

\section{Press.}

(2010): Labor Markets and Business Cycles. Princeton University

Zanetti, F. (2007): "A Non-Walrasian Labor Market in a Monetary Model of the Business Cycle," Journal of Economic Dynamics and Control, 31, 24132437.

ZanetTi, F. (2011): "Labor market institutions and aggregate fluctuations in a search and matching model," European Economic Review, 55(5), 644-658. 


\section{A Optimality Conditions under Individual Wage Bargaining}

\section{A.1 Vacancy Posting Decision under Individual Wage Bargaining}

Under individual wage bargaining, although wages are bargained once the employment level is determined, firms anticipate the outcome of the wage bargaining when deciding on the number of vacancies to post. With this timing, if wages in a firm would depend on this firm's employment size, the firm would have the possibility to modulate the wage through its employment policy. For simplicity reason, I assume constant returns to scale in the production function so that the intra-firm bargaining element vanishes. ${ }^{25}$ As a result, the profit's maximization is not constrained by the wage equation $w_{t}=w_{t}\left(n_{t}\right)$ and the number of posted vacancies results from the following profit maximization process:

$$
\begin{aligned}
& \max _{v_{t}} F_{t}\left(n_{t}\right)=z_{t} n_{t}-w_{t} n_{t}-c v_{t}+E_{t} \beta F_{t+1}\left(n_{t+1}\right) \\
& \text { s.t. } n_{t}=(1-\lambda) n_{t-1}+q_{t} v_{t}
\end{aligned}
$$

which is identical to the case of collective wage bargaining. Therefore, under both wage-setting processes, the job creation curve is described by Equation (5).

\section{A.2 Wage Negotiation under Individual Bargaining}

Once the match is formed, the individual wage bargaining process takes place between the firm and the worker. The Nash-bargained wage maximizes the product of the net gains of agreement for both parties:

$$
\max _{w_{t}}\left[W_{t}-U_{t}\right]^{\eta^{I}}\left[J_{t}\right]^{1-\eta^{I}}
$$

where $\eta^{I} \in[0,1]$ is the workers' bargaining power.

The first-order condition states that the worker share of the total surplus is equal to the workers' bargaining power:

$$
\frac{W_{t}-U_{t}}{W_{t}-U_{t}+J_{t}}=\eta^{I}
$$

By rearranging this first-order condition and using the expression of the values $J_{t}, W_{t}$ and $U_{t}$, I obtain the equilibrium wage equation:

$$
w_{t}=\eta^{I}\left[z_{t}+E_{t} \beta(1-\lambda) c \theta_{t+1}\left(z_{t+1}\right)\right]+\left(1-\eta^{I}\right) b
$$

The bargaining set is delimited by two threat points and contains an infinity of equilibrium wage rates. The optimal sharing rule allocates a constant share of the bargaining set to the worker and the firm.

\footnotetext{
${ }^{25}$ See Cahuc and Wasmer (2001).
} 


\section{B Profit of the Firms and Marginal Value of Employment}

The firms' profit satisfies the following Bellman equation:

$$
F_{t}=z_{t} n_{t}-w_{t} n_{t}-c v_{t}+E_{t} \beta F_{t+1}
$$

The Bellman equation of the firms' marginal value of employment is:

$$
J_{t}=z_{t}-w_{t}+E_{t} \beta(1-\lambda) J_{t+1}
$$

Therefore:

$$
\begin{aligned}
& F_{t}=n_{t} J_{t}-n_{t} E_{t} \beta(1-\lambda) J_{t+1}-c v_{t} \\
& +E_{t} \beta\left[n_{t+1} J_{t+1}-n_{t+1} E_{t} \beta(1-\lambda) J_{t+2}-c v_{t+1}\right] \\
& \quad+E_{t} \beta^{2}\left[n_{t+2} J_{t+2}-n_{t+2} E_{t} \beta(1-\lambda) J_{t+3}-c v_{t+2}\right]+E_{t} \beta^{3} \ldots
\end{aligned}
$$

Using the law of motion of employment, $n_{t+1}=(1-\lambda) n_{t}+q_{t+1} v_{t+1}$, I obtain:

$$
\begin{aligned}
& F_{t}=n_{t} J_{t}-c v_{t} \\
& \quad+E_{t} \beta\left[n_{t+1} J_{t+1}-n_{t+1} J_{t+1}-c v_{t+1}+q_{t+1} v_{t+1} J_{t+1}\right] \\
& \quad+E_{t} \beta^{2}\left[n_{t+2} J_{t+2}-n_{t+2} J_{t+2}-c v_{t+2}+q_{t+2} v_{t+2} J_{t+2}\right]+E_{t} \beta^{3} \ldots
\end{aligned}
$$

Because $J_{t}=\frac{c}{q_{t}}$, I get:

$$
\begin{aligned}
& F_{t}=n_{t} J_{t}-c v_{t}+E_{t} \beta\left[-c v_{t+1}+c v_{t+1}\right]+E_{t} \beta^{2}\left[-c v_{t+2}+c v_{t+2}\right]+E_{t} \beta^{3} \ldots \\
& F_{t}=n_{t} J_{t}-c v_{t}
\end{aligned}
$$

\section{Equilibrium Wage under Collective Wage Bar- gaining}

\section{C.1 Worker Share under Firm-Level Collective Wage Bargaining}

The union's maximization program is the following:

$$
\begin{aligned}
& \max _{w_{t}}\left[n_{t}\left(W_{t}-U_{t}\right)\right]^{\eta^{C}}\left[F_{t}\right]^{1-\eta^{C}} \\
& \text { s.t job creation equation: } \frac{c}{q_{t}}=z_{t}-w_{t}+E_{t} \beta(1-\lambda) \frac{c}{q_{t+1}}
\end{aligned}
$$

Plugging the job creation curve, Equation (5), and the Bellman equation for the firms' ex-post employment value of marginal match, $J_{t}$, into Equation (17), we obtain $F_{t}=(1-\lambda) n_{t-1} J_{t}$. Using this equation, we obtain the following F.O.C. of the maximization program: 
$\eta^{C}\left[\frac{\partial n_{t}}{\partial w_{t}}\left(W_{t}-U_{t}\right)+n_{t} \frac{\partial W_{t}}{\partial w_{t}}\right](1-\lambda) n_{t-1} J_{t}+\left(1-\eta^{C}\right)(1-\lambda) n_{t-1} \frac{\partial J_{t}}{\partial w_{t}}\left[n_{t}\left(W_{t}-U_{t}\right)\right]=0$

The law of motion of employment is $n_{t}=1-u_{t}+q_{t} v_{t}$. In case of firm-level negotiation, unions are too small to influence the market, therefore, using (5), we obtain:

$$
\frac{\partial n_{t}}{\partial w_{t}}=-\frac{m_{t}}{\sigma_{u} J_{t}}
$$

Using this derivative, the F.O.C. can be rewritten as:

$$
-\eta^{C} \frac{m_{t}}{\sigma_{u} J_{t}}\left(W_{t}-U_{t}\right) J_{t}+\eta^{C} n_{t} J_{t}=\left(1-\eta^{C}\right) n_{t}\left(W_{t}-U_{t}\right)
$$

Rearranging leads to:

$$
W_{t}-U_{t}=\frac{\eta^{C} \sigma_{u}}{\sigma_{u}\left(1-\eta^{C}\right)+\eta^{C} \frac{m_{t}}{n_{t}}} J_{t}
$$

and

$$
\frac{W_{t}-U_{t}}{W_{t}-U_{t}+J_{t}}=\frac{\eta^{C} \sigma_{u}}{\sigma_{u}+\eta^{C} \frac{m_{t}}{n_{t}}}
$$

which is equivalent to Equation (9).

\section{C.2 Worker Share under Economy-Wide Collective Wage Bargaining}

The maximization program and F.O.C. are identical to the case of firm-level wage bargaining:

$\eta^{C}\left[\frac{\partial n_{t}}{\partial w_{t}}\left(W_{t}-U_{t}\right)+n_{t} \frac{\partial W_{t}}{\partial w_{t}}\right](1-\lambda) n_{t-1} J_{t}+\left(1-\eta^{C}\right)(1-\lambda) n_{t-1} \frac{\partial J_{t}}{\partial w_{t}}\left[n_{t}\left(W_{t}-U_{t}\right)\right]=0$

The law of motion of employment is $n_{t}=1-u_{t}+q_{t} v_{t}$. In case of economywide wage negotiation, unions internalize the wage effect on the vacancy filling rate. Therefore, using (5), we obtain:

$$
\frac{\partial n_{t}}{\partial w_{t}}=-\frac{\left(1-\sigma_{u}\right) m_{t}}{\sigma_{u} J_{t}}
$$

Using this derivative, the F.O.C. can be rewritten as: 


$$
-\eta^{C} \frac{\left(1-\sigma_{u}\right) m_{t}}{\sigma_{u} J_{t}}\left(W_{t}-U_{t}\right) J_{t}+\eta^{C} n_{t} J_{t}=\left(1-\eta^{C}\right) n_{t}\left(W_{t}-U_{t}\right)
$$

Rearranging leads to:

$$
W_{t}-U_{t}=\frac{\eta^{C} \sigma_{u}}{\sigma_{u}\left(1-\eta^{C}\right)+\eta^{C}\left(1-\sigma_{u}\right) \frac{m_{t}}{n_{t}}} J_{t}
$$

and

$$
\frac{W_{t}-U_{t}}{W_{t}-U_{t}+J_{t}}=\frac{\eta^{C} \sigma_{u}}{\sigma_{u}+\eta^{C}\left(1-\sigma_{u}\right) \frac{m_{t}}{n_{t}}}
$$

which is equivalent to Equation (12).

\section{C.3 Wage Curve under Collective Wage Bargaining}

The functional form of the wage curve is independent of the level of wage bargaining (firm level or economy-wide).

Plugging the workers' value functions of employment and unemployment, Equations (6) and (7), into each other, I obtain:

$$
W_{t}-U_{t}=w_{t}-b+E_{t}(1-\lambda) \beta\left(1-p_{t+1}\right)\left(W_{t+1}-U_{t+1}\right)
$$

Using the equilibrium condition (9), we can rewrite this equation as:

$\frac{\eta^{C} \sigma_{u}}{\sigma_{u}\left(1-\eta^{C}\right)+\eta^{C}\left(1-\sigma_{u}\right) \frac{m_{t}}{n_{t}}} J_{t}=w_{t}-b+E_{t}(1-\lambda) \beta\left(1-p_{t+1}\right) \frac{\eta^{C} \sigma_{u}}{\sigma_{u}\left(1-\eta^{C}\right)+\eta^{C}\left(1-\sigma_{u}\right) \frac{m_{t+1}}{n_{t+1}}} J_{t+1}$

Plugging the value of firms' value function of employment into this equation, I get:

$$
\begin{aligned}
& \frac{\eta^{C} \sigma_{u}}{\sigma_{u}\left(1-\eta^{C}\right)+\eta^{C}\left(1-\sigma_{u}\right) \frac{m_{t}}{n_{t}}}\left(z_{t}-w_{t}+E_{t} \beta(1-\lambda) \frac{c}{q_{t+1}}\right) \\
& \quad=w_{t}-b+E_{t}(1-\lambda) \beta\left(1-p_{t+1}\right) \frac{\eta^{C} \sigma_{u}}{\sigma_{u}\left(1-\eta^{C}\right)+\eta^{C}\left(1-\sigma_{u}\right) \frac{m_{t+1}}{n_{t+1}}} \frac{c}{q_{t+1}}
\end{aligned}
$$

Rearranging leads to: 


$$
\begin{aligned}
& w_{t}=\frac{\eta^{C} \sigma_{u}}{\sigma_{u}+\eta\left(1-\sigma_{u}\right) \frac{m_{t}}{n_{t}}}\left[z_{t}+E_{t} \beta(1-\lambda) \frac{c}{q_{t+1}}\right] \\
& +\frac{\sigma_{u}\left(1-\eta^{C}\right)+\eta^{C}\left(1-\sigma_{u}\right) \frac{m_{t}}{n_{t}}}{\sigma_{u}+\eta^{C}\left(1-\sigma_{u}\right) \frac{m_{t}}{n_{t}}}\left[b-E_{t}(1-\lambda) \beta\left(1-p_{t+1}\right) \frac{\eta^{C} \sigma_{u}}{\sigma_{u}\left(1-\eta^{C}\right)+\eta^{C}\left(1-\sigma_{u}\right) \frac{m_{t+1}}{n_{t+1}}} \frac{c}{q_{t+1}}\right] \\
& w_{t}=\tilde{\eta}_{t}\left[z_{t}+E_{t} \beta(1-\lambda) \frac{c}{q_{t+1}}\right]+\left(1-\tilde{\eta}_{t}\right)\left[b-E_{t} \beta(1-\lambda)\left(1-p_{t+1}\right) \frac{\tilde{\eta}_{t+1}}{1-\tilde{\eta}_{t+1}} \frac{c}{q_{t+1}}\right]
\end{aligned}
$$

where $\tilde{\eta}_{t}$ is defined by Equation (14).

$$
w_{t}=\tilde{\eta}_{t}\left[z_{t}+E_{t} \beta(1-\lambda) c \theta_{t+1}\right]+\left(1-\tilde{\eta}_{t}\right) b-\left[E_{t} \beta(1-\lambda) \frac{c}{q_{t+1}}\left(1-p_{t+1}\right)\right]\left[\frac{\tilde{\eta}_{t+1}-\tilde{\eta}_{t}}{1-\tilde{\eta}_{t+1}}\right]
$$

This is equivalent to Equation (13). A similar method can be applied to obtain Equations (11) and (10).

\section{C.4 Cyclical Properties of the Worker Share}

The derivative of the worker share with respect to the job finding rate is:

$$
\begin{gathered}
\frac{\partial \tilde{\eta}_{t}}{\partial p_{t}}=\eta^{C} \frac{\sigma_{u}\left[\sigma_{u}\left(\frac{1}{u_{t}}-1\right)+\left(\eta\left(1-\sigma_{u}\right)+\sigma_{u}\right) p_{t}\right]-\left(\eta^{C}\left(1-\sigma_{u}\right)+\sigma_{u}\right) \sigma_{u}\left(\frac{1}{u_{t}}-1+p_{t}\right)}{\left(\sigma_{u}\left(\frac{1}{u_{t}}-1\right)+\left(\eta^{C}\left(1-\sigma_{u}\right)+\sigma_{u}\right) p_{t}\right)^{2}} \\
\frac{\partial \tilde{\eta}_{t}}{\partial p_{t}}=-\eta^{C} \frac{\eta^{C}\left(1-\sigma_{u}\right) \sigma_{u}\left(\frac{1}{u_{t}}-1\right)}{\left(\sigma_{u}\left(\frac{1}{u_{t}}-1\right)+\left(\eta^{C}\left(1-\sigma_{u}\right)+\sigma_{u}\right) p_{t}\right)^{2}}<0
\end{gathered}
$$

The derivative of the worker share with respect to the beginning-of-period stock of unemployed workers is:

$$
\begin{aligned}
\frac{\partial \tilde{\eta}_{t}}{\partial u_{t}} & =\eta^{C} \frac{\frac{-\sigma_{u}}{u_{t}^{2}}\left[\sigma_{u}\left(\frac{1}{u_{t}}-1\right)+\left(\eta^{C}\left(1-\sigma_{u}\right)+\sigma_{u}\right) p_{t}\right]+\frac{\sigma_{u}}{u_{t}^{2}}\left(\sigma_{u}\left(\frac{1}{u_{t}}-1+p_{t}\right)\right)}{\left(\sigma_{u}\left(\frac{1}{u_{t}}-1\right)+\left(\eta^{C}\left(1-\sigma_{u}\right)+\sigma_{u}\right) p_{t}\right)^{2}} \\
\frac{\partial \tilde{\eta}_{t}}{\partial u_{t}} & =\eta^{C} \frac{\frac{-\sigma_{u}}{u_{t}^{2}} \eta^{C}\left(1-\sigma_{u}\right)}{\left(\sigma_{u}\left(\frac{1}{u_{t}}-1\right)+\left(\eta^{C}\left(1-\sigma_{u}\right)+\sigma_{u}\right) p_{t}\right)^{2}}<0
\end{aligned}
$$




\section{C.5 Marginal Rate of Substitution of Wage for Employ- ment}

$$
\begin{aligned}
M R S_{w_{t}, n_{t}} & =-\frac{\partial n_{t}}{\partial w_{t}}=\frac{\frac{\partial \Omega_{t}}{\partial w_{t}}}{\frac{\partial \Omega_{t}}{\partial n_{t}}} \\
M R S_{w_{t}, n_{t}} & =-\frac{\left(1-\sigma_{u}\right) m_{t}}{\sigma_{u} J_{t}}+\frac{n_{t}}{W_{t}-U_{t}}
\end{aligned}
$$

Using $W_{t}-U_{t}=\frac{\tilde{\eta}_{t}}{1-\tilde{\eta}_{t}} J_{t}$, we get:

$$
\begin{aligned}
& M R S_{w_{t}, n_{t}}=\frac{1}{J_{t}}\left[\frac{1-\tilde{\eta}_{t}}{\tilde{\eta}_{t}} n_{t}-\frac{\left(1-\sigma_{u}\right) m_{t}}{\sigma_{u}}\right] \\
& M R S_{w_{t}, n_{t}}=\frac{q_{t}}{c}\left[\frac{n_{t}\left(1-\eta^{C}\right) \sigma_{u}+\eta^{C}\left(1-\sigma_{u}\right) m_{t}}{\eta^{C} \sigma_{u}}-\frac{\left(1-\sigma_{u}\right) m_{t}}{\sigma_{u}}\right] \\
& M R S_{w_{t}, n_{t}}=\frac{1-\eta^{C}}{\eta^{C}} \frac{n_{t} q_{t}}{c} \\
& \frac{\partial M R S_{w_{t}^{U}, n_{t}^{U}}}{\partial z_{t}}=\frac{1-\eta^{C}}{c \eta^{C}}\left[\frac{\partial n_{t}}{\partial z_{t}} q_{t}+\frac{\partial q_{t}}{\partial z_{t}} n_{t}\right] \\
& \frac{\partial M R S_{w_{t}^{U}, n_{t}^{U}}}{\partial z_{t}}=\frac{1-\eta^{C}}{c \eta^{C}}\left[\frac{\partial m_{t}}{\partial z_{t}} q_{t}+\frac{\partial m_{t}}{\partial z_{t}} \frac{n_{t}}{v_{t}}-\frac{\partial v_{t}}{\partial z_{t}} \frac{q_{t} n_{t}}{v_{t}}\right] \\
& \frac{\partial M R S_{w_{t}^{U}, n_{t}^{U}}}{\partial z_{t}}=\frac{1-\eta^{C}}{c \eta^{C}} \frac{\partial m_{t}}{\partial z_{t}}\left[m_{t}-\sigma_{u}\left(n_{t}+m_{t}\right)\right]<0
\end{aligned}
$$

because $m_{t}-\sigma_{u}\left(n_{t}+m_{t}\right)<0$ under standard calibration.

\section{C.6 Linearization}

In order to analyze the channels through which the productivity shock affects the labor market, I consider a log-linear approximation of the equilibrium conditions (Equations (5), (13) and (15)), of the laws of motion of employment and unemployment, and of the equations defining matches, vacancy filling rate, job finding rate, and labor market tightness. The hat operator denotes logdeviation from the steady state.

- (End-of-period) employment dynamics:

$$
\hat{n}_{t}=-\frac{\lambda}{p} \hat{u}_{t}+\lambda \hat{m}_{t}
$$

- (Beginning-of-period) unemployment dynamics:

$$
\hat{u}_{t}=-\frac{p}{\lambda}(1-\lambda) \hat{n}_{t-1}
$$


Using these two equations, I can write:

$$
\hat{n}_{t}=(1-\lambda) \hat{n}_{t-1}+\lambda \hat{m}_{t}
$$

- Matching process:

$$
\hat{m}_{t}=\sigma_{u} \hat{u}_{t}+\left(1-\sigma_{u}\right) \hat{v}_{t}
$$

- Vacancy filling rate:

$$
\hat{q}_{t}=\hat{m}_{t}-\hat{v}_{t}
$$

- Job finding rate:

$$
\hat{p}_{t}=\hat{m}_{t}-\hat{u}_{t}
$$

- Labor market tightness:

$$
\hat{\theta}_{t}=\hat{v}_{t}-\hat{u}_{t}
$$

- JC curve:

$$
\hat{\theta}_{t}=\phi \hat{z}_{t}-\phi \bar{w} \hat{w}_{t}+\beta(1-\lambda) \hat{\theta}_{t+1}
$$

where $\bar{w}=\frac{w}{z}, \phi=\frac{1}{\sigma_{u} C}$ and $C=\frac{c}{z q}$.

- Wage rate:

Individual wage bargaining:

$$
\hat{w}_{t}=\frac{\eta^{I}}{\bar{w}} \hat{z}_{t}+\frac{\eta^{I}}{\bar{w}}[\beta(1-\lambda) \bar{c} \theta] \hat{\theta}_{t+1}
$$

Collective wage bargaining:

$$
\hat{w}_{t}=\frac{\tilde{\eta}}{\bar{w}} \hat{z}_{t}+\frac{\tilde{\eta}}{\bar{w}}[\beta(1-\lambda) \bar{c} \theta] \hat{\theta}_{t+1}+\frac{\tilde{\eta}}{\bar{w}}[(1-\bar{b})+\beta(1-\lambda) \bar{c} \theta] \hat{\tilde{\eta}}_{t}+\hat{\tilde{O}}_{t}
$$

where $\hat{\tilde{O}}_{t}=\frac{1}{\bar{w}}\left[\beta(1-\lambda) C(1-p) \frac{\tilde{\eta}}{1-\tilde{\eta}}\right]\left(\hat{\tilde{\eta}}_{t}-\hat{\tilde{\eta}}_{t+1}\right)$

and $\bar{b}=\frac{b}{z}, \bar{c}=\frac{c}{z}$ and $C=\frac{c}{z q}$.

- Worker share (for collective wage bargaining):

$$
\hat{\tilde{\eta}}_{t}=-\left(\gamma\left(1-\lambda+\frac{\lambda}{p}\right)\right) \hat{u}_{t}-\left(\gamma\left(1-\sigma_{u}\right)(1-\lambda)\right) \hat{\theta}_{t}
$$

where $\gamma=\frac{\eta^{C}\left(1-\sigma_{u}\right) \lambda}{\eta^{C}\left(1-\sigma_{u}\right) \lambda+\sigma_{u}}$. 


\section{Extension: Insider vs. Outsider}

The maximization program is identical to the case of firm-level and economylevel wage bargaining:

$$
\begin{aligned}
& \max _{w_{t}}\left[n_{t}\left(W_{t}-U_{t}\right)\right]^{\eta^{C}}\left[F_{t}\right]^{1-\eta^{C}} \\
& \text { s.t job creation equation: } \frac{c}{q_{t}}=z_{t}-w_{t}+E_{t} \beta(1-\lambda) \frac{c}{q_{t+1}}
\end{aligned}
$$

Plugging the job creation curve, Equation (5) and the Bellman equation for the firms' ex-post employment value of marginal match, $J_{t}$, into Equation (17), one obtains $F_{t}=(1-\lambda) n_{t-1} J_{t}$. Using this equation, we obtain the following F.O.C. of the maximization program:

$\eta^{C}\left[\frac{\partial n_{t}}{\partial w_{t}}\left(W_{t}-U_{t}\right)+n_{t} \frac{\partial W_{t}}{\partial w_{t}}\right](1-\lambda) n_{t-1} J_{t}+\left(1-\eta^{C}\right)(1-\lambda) n_{t-1} \frac{\partial J_{t}}{\partial w_{t}}\left[n_{t}\left(W_{t}-U_{t}\right)\right]=0$

Using the law of motion of employment and the job creation curve, Equation (5), we obtain:

$$
\frac{\partial n_{t}}{\partial w_{t}}=-\frac{\left(1-\sigma_{u}\right) m_{t}}{\sigma_{u} J_{t}}
$$

In this extension, unions internalize how a change in wages in time $t$ will affect the job finding rate in time $t+1$ and, through this channel, how it will affect the worker surplus in $t+1$. Therefore:

$$
\frac{\partial W_{t}}{\partial w_{t}}=1+\psi_{t}
$$

where $\psi_{t}=\beta(1-\lambda)^{2} \frac{\left(1-\sigma_{u}\right)^{2}}{\sigma_{u}} \frac{p_{t+1}}{u_{t+1}} \frac{m_{t}}{J_{t}}\left(W_{t+1}-U_{t+1}\right)$.

Using these derivatives, the F.O.C. of the maximization program is:

$$
-\eta^{C} \frac{m_{t}}{\sigma_{u} J_{t}}\left(W_{t}-U_{t}\right) J_{t}+\eta^{C} n_{t}\left(1+\psi_{t}\right) J_{t}=\left(1-\eta^{C}\right) n_{t}\left(W_{t}-U_{t}\right)
$$

Rearranging leads to:

$$
W_{t}-U_{t}=\frac{\eta^{C} \sigma_{u}\left(1+\psi_{t}\right)}{\sigma_{u}\left(1-\eta^{C}\right)+\eta^{C}\left(1-\sigma_{u}\right) \frac{m_{t}}{n_{t}}} J_{t}
$$

and

$$
\frac{W_{t}-U_{t}}{W_{t}-U_{t}+J_{t}}=\frac{\eta^{C} \sigma_{u}\left(1+\psi_{t}\right)}{\sigma_{u}+\eta^{C} \sigma_{u} \psi_{t}+\eta^{C}\left(1-\sigma_{u}\right) \frac{m_{t}}{n_{t}}}
$$

which is equivalent to Equation (16). 
Figure 1: Impulse Responses of the Labor Market to a Positive Productivity Shock
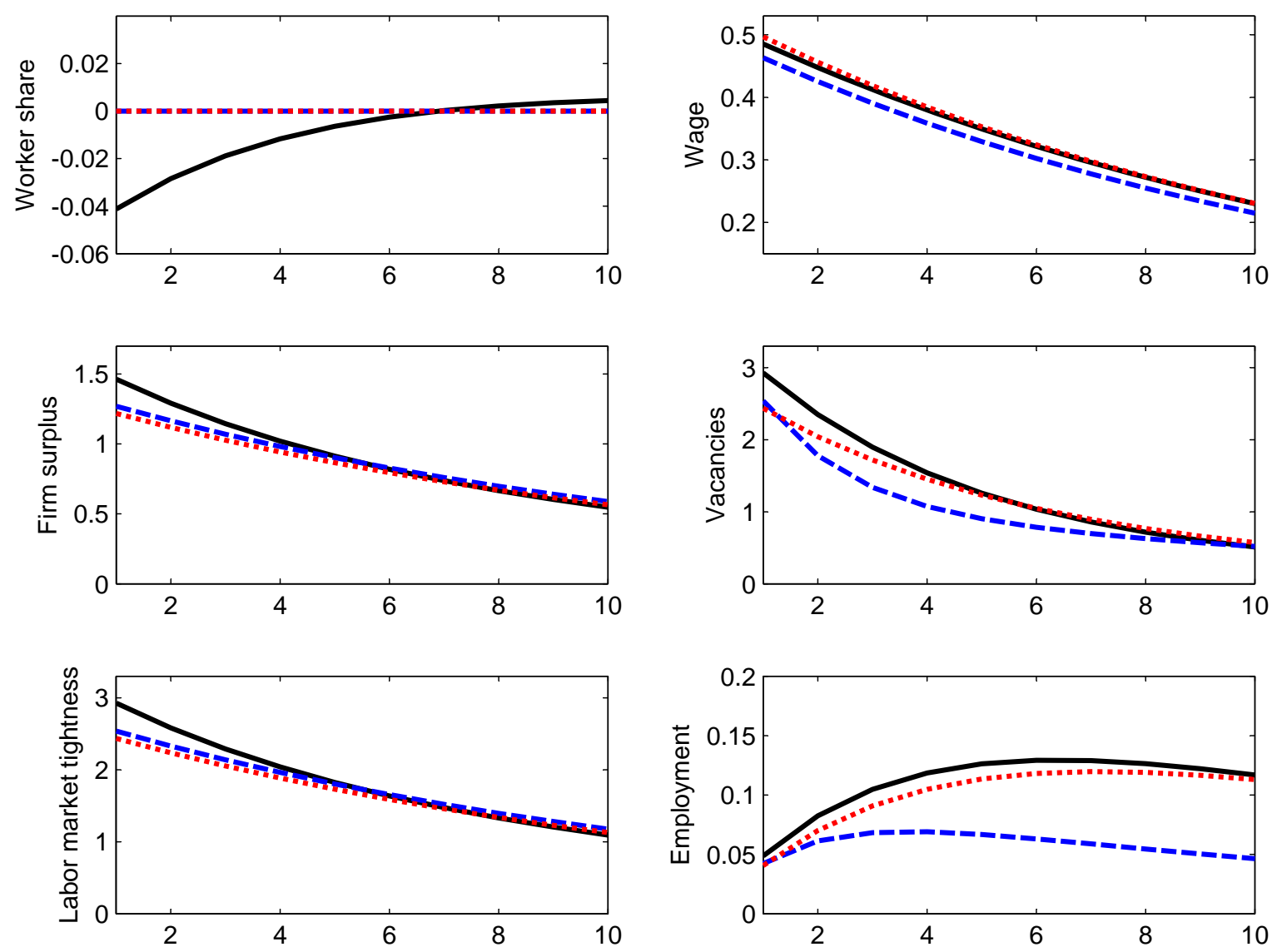

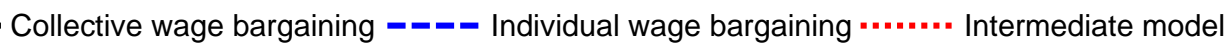

Note: Percentage deviation from the steady state following a positive productivity shock of one standard deviation. The intermediate model is characterized by (a) individual wage bargaining and (b) high worker bargaining power such that the steady state is identical to the steady state prevailing in the collective wage bargaining model. 
Figure 2: Impulse Responses of the Labor Market to a Positive Productivity
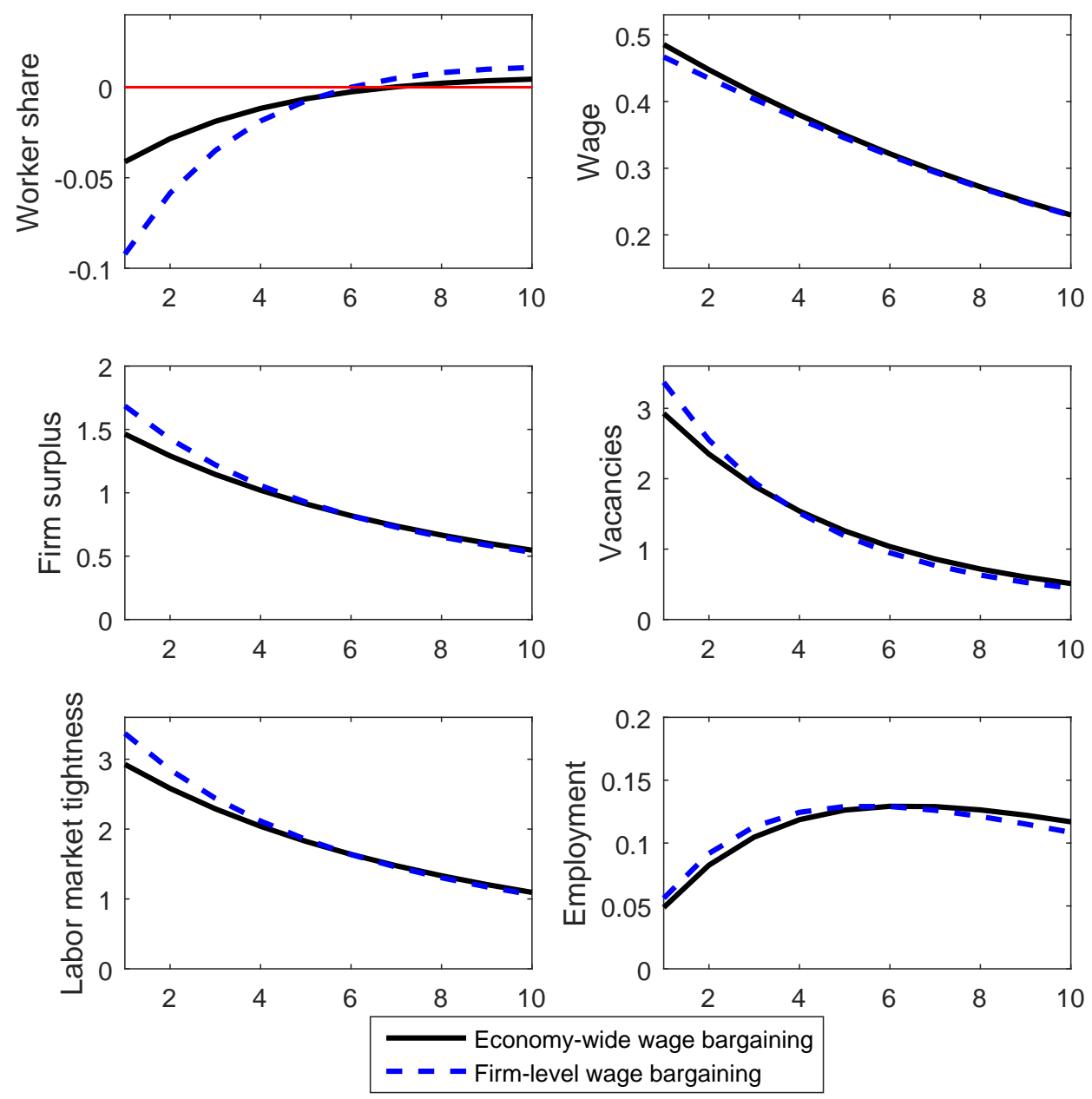

Note: Percentage deviation from the steady state following a positive productivity shock of one standard deviation. 
Figure 3: Alternative Values of the Union's Bargaining Power
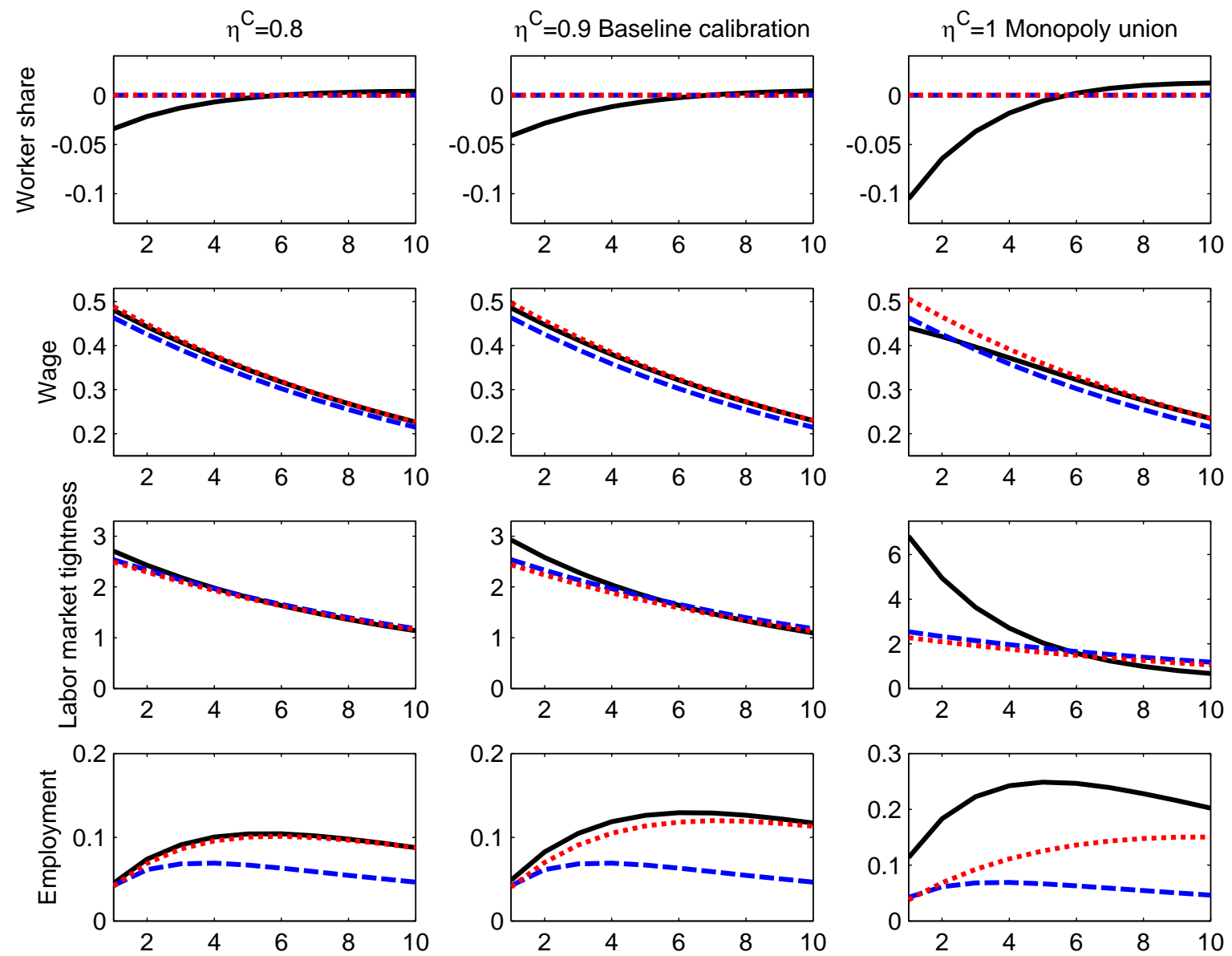

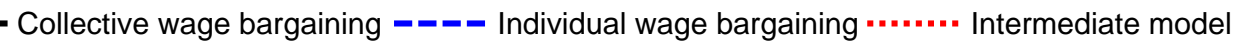

Note: Percentage deviation from the steady state following a positive productivity shock of one standard deviation. The intermediate model is characterized by (a) individual wage bargaining and (b) high worker bargaining power such that the steady state is identical to the steady state prevailing in the collective wage bargaining model. 
Figure 4: Alternative Value of the Union Separation Rate
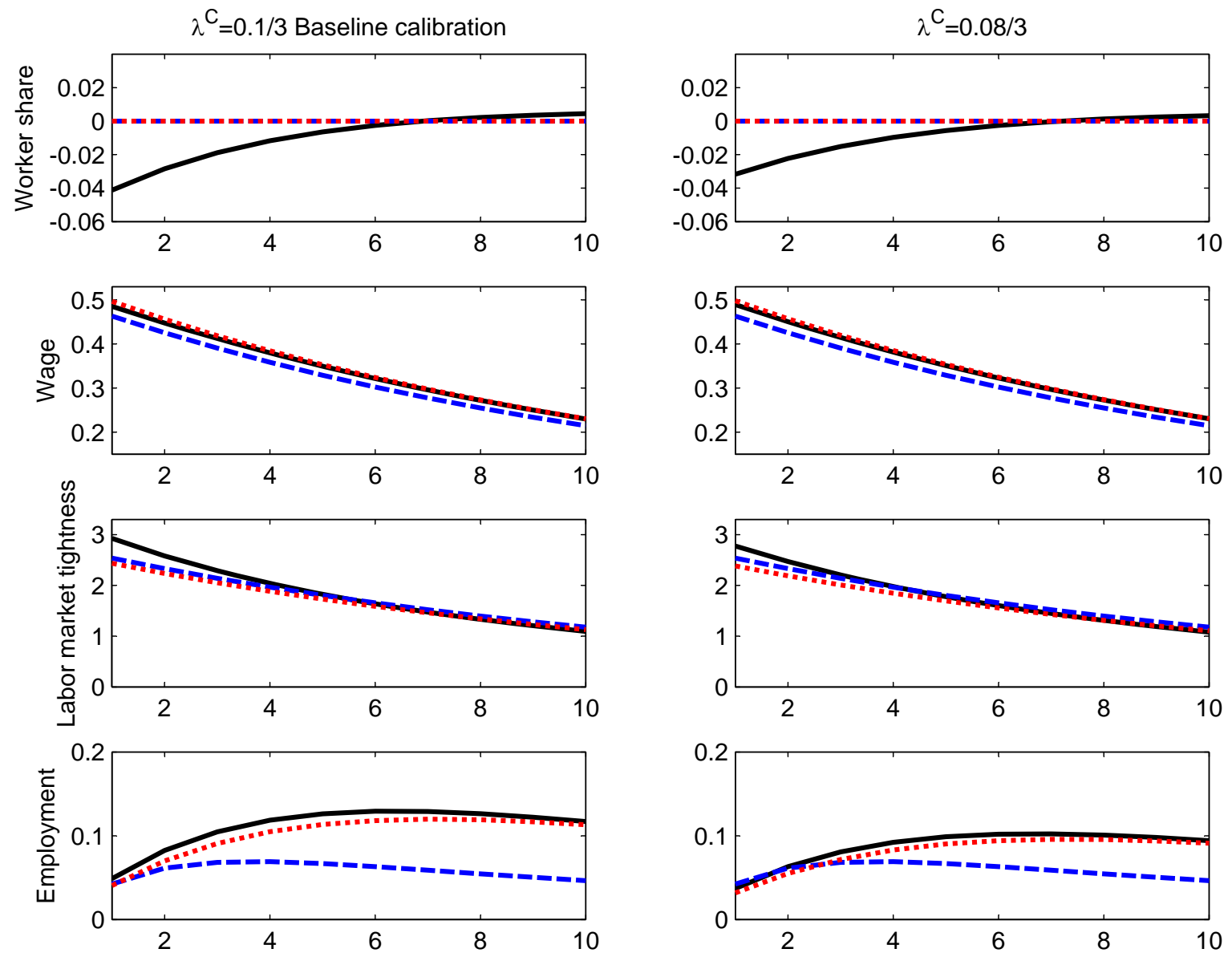

Collective wage bargaining ---- Individual wage bargaining........ Intermediate model

Note: Percentage deviation from the steady state following a positive productivity shock of one standard deviation. I maintain the separation rate equal to $\lambda^{I}=0.1 / 3$ in the individual wage-bargaining model and show the effect of a 20-percent decrease in the separation rate in the collective wage bargaining model $\left(\lambda^{C}=0.08 / 3\right)$. The intermediate model is characterized by (a) individual wage bargaining and (b) high worker bargaining power and a low separation rate such that the steady state is identical to the steady state prevailing in the collective wage bargaining model. 
Figure 5: Impulse Responses of the Labor Market to a Positive Productivity Shock
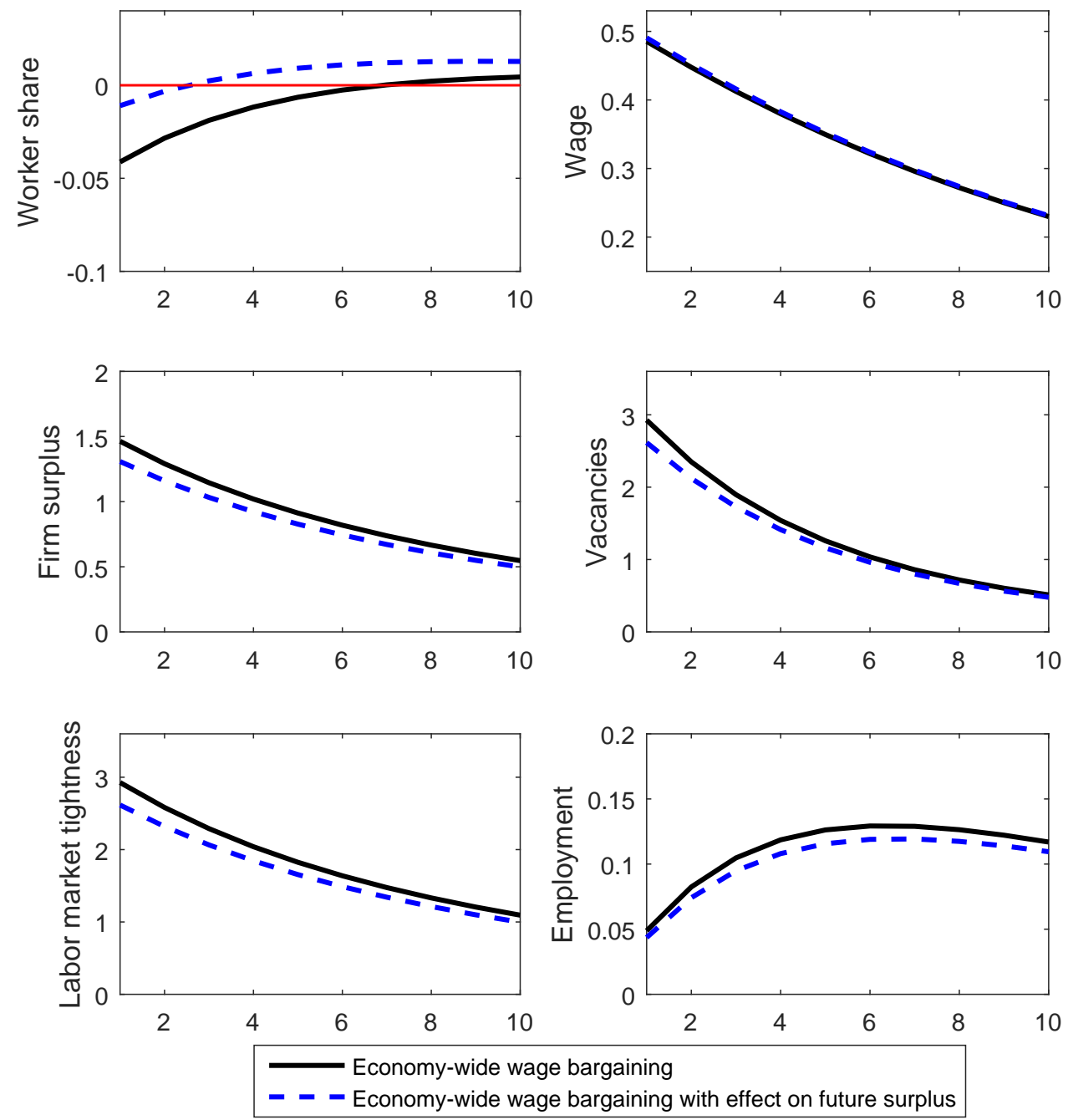

Note: Percentage deviation from the steady state following a positive productivity shock of one standard deviation. Workers, and therefore unions, now take into account that high wages, by lowering the future probability for unemployed workers to find jobs, increase the future surplus of employed workers. 